\title{
Phycochemical Constituents and Biological Activities of Fucus spp.
}

\author{
Marcelo D. Catarino, Artur M. S. Silva ${ }^{(D)}$ and Susana M. Cardoso * \\ Department of Chemistry \& Organic Chemistry, Natural Products and Food Stuffs Research Unit (QOPNA), \\ University of Aveiro, Aveiro 3810-193, Portugal; mcatarino@ua.pt (M.D.C.); artur.silva@ua.pt (A.M.S.S.) \\ * Correspondence: susanacardoso@ua.pt; Tel.: +351-234-370-360; Fax: +351-234-370-084
}

Received: 27 June 2018; Accepted: 23 July 2018; Published: 27 July 2018

\begin{abstract}
Seaweeds are known to be a good supply of key nutrients including carbohydrates, protein, minerals, polyunsaturated lipids, as well as several other health-promoting compounds capable of acting on a wide spectrum of disorders and/or diseases. While these marine macroalgae are deeply rooted in the East Asian culture and dietary habits, their major application in Western countries has been in the phycocolloid industry. This scenario has however been gradually changing, since seaweed consumption is becoming more common worldwide. Among the numerous edible seaweeds, members of the genus Fucus have a high nutritional value and are considered good sources of dietary fibers and minerals, especially iodine. Additionally, their wealth of bioactive compounds such as fucoidan, phlorotannins, fucoxanthin and others make them strong candidates for multiple therapeutic applications (e.g., antioxidant, anti-inflammatory, anti-tumor, anti-obesity, anti-coagulant, anti-diabetes and others). This review presents an overview of the nutritional and phytochemical composition of Fucus spp., and their claimed biological activities, as well as the beneficial effects associated to their consumption. Furthermore, the use of Fucus seaweeds and/or their components as functional ingredients for formulation of novel and enhanced foods is also discussed.
\end{abstract}

Keywords: Fucus spp.; nutritional value; bioactivities; fucoidan; phlorotannins; fucoxanthin

\section{Introduction}

Seaweeds, i.e., marine macroalgae, have a long tradition of usage and applications among the far East populations, either for direct consumption and nutrition or for medicinal purposes, whereas, in Western countries, their industrial utilization has been rather confined to extraction of phycocolloids and, to a lesser extent, certain fine biochemicals [1]. Nevertheless, this panorama is currently shifting as macroalgae are becoming more and more popular since, in addition to not competing with food crops for the use of arable land and fresh water resources, they are claimed to be a good supply of key nutrients including carbohydrates, protein and minerals [2], as well as a rich source of health-promoting compounds capable of acting on a wide spectrum of disorders and/or diseases [3]. Note also that the Japanese have the world's longest life expectancy, which has been partly associated with their different dietary patterns, and of course, the regular consumption of macroalgae [4]. Based on this evidence, marine macroalgae are presently pointed out as the plant-based food of the future, and their regular consumption among Western population has been trending upward [5]. Indeed, the global functional food market, which was valued at US \$168 in 2013 and expected to exceed US \$305.4 billion by 2020, is believed to be one of the most important exploiting opportunities where direct applications of seaweeds, crude extracts or purified fractions of seaweeds might hold potential [4].

Fucus, an abundant and widely distributed genus of brown, perennial and edible seaweeds, has earned increasing attention throughout the last years. This genus occupies the cold-temperate waters from the littoral and sublittoral regions along the rocky shorelines of the northern hemisphere 
(Figure 1) [6], and is comprised of 66 currently accepted taxonomically species all characterized by a greenish brown trisected thallus, i.e., a structure consisting of a holdfast, a small stipe and flattened dichotomously-branched blades with terminal receptacles that swell during the reproductive season. The blades usually have a central-thickened area called midrib and, in some species, air bladders can be found to keep them floating in a vertical position when submerged [7].

F. vesiculosus is the most well-known species from Fucus genus, often dominating shallow macroalgae communities. It grows on the mid-tide zone of high salinity waters forming large belts that have an important role in the structure of the habitats that harbor species-rich epiphytic and epibenthic communities [8]. Other important species from this genus include F. spiralis and F. serratus, the former growing in the upper intertidal zone and the latter in the lower-mid intertidal zone $[9,10]$.

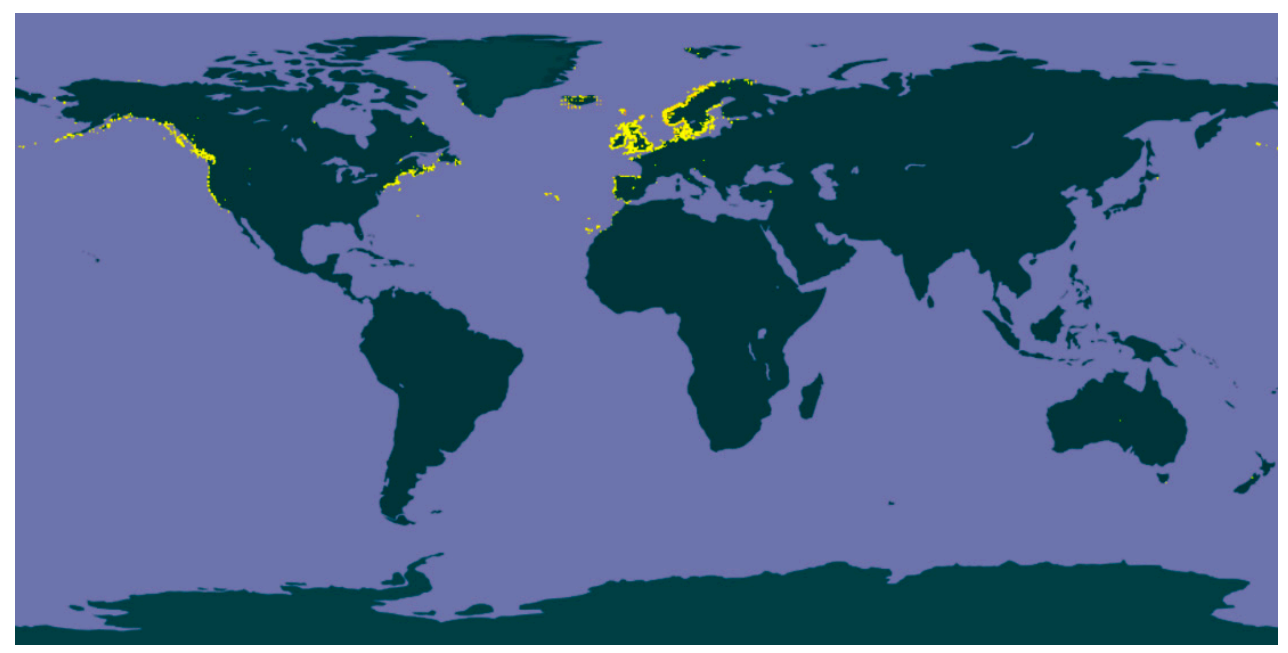

Figure 1. Geographical distribution of Fucus L. (C) OpenStreetMap contributors (licensed under Open Data Commons Open Database License); GBIF.org (25 July 2018) GBIF Occurrence Download https: / / doi.org/10.15468/dl.15mbpr (licensed under CC BY 4.0).

With high content in dietary fiber, minerals and vitamins, and low in fat, seaweeds belonging to this genus have an exceptional combination of macro- and micronutrients that make them very interesting from a nutritional perspective. In fact, several Fucus spp. have long been harvested and used as food sources mainly in far East Asian countries, but also in some coastal countries of Western Europe and Alaska [11]. In particular, F. spiralis is a popular delicacy in the Azores Islands where its swollen receptacles are very appreciated and known as sea lupines [12].

In traditional medicine, Fucus spp. became very popular mainly due to their high content in iodine, which renders them remarkable therapeutic properties for treating goiter, i.e., the swelling of thyroid and thyroid-related complications, and obesity [13]. Moreover, this genus is also an excellent source of bioactive compounds such as fucoidans, phlorotannins and fucoxanthin, which have been repeatedly shown to possess important therapeutic properties including the treatment of cellulite, blood clot formations, rheumatoid arthritis, asthma, atherosclerosis, diabetes, psoriasis and skin diseases, cancer and other oxidative and inflammatory related conditions [14-17]. Thanks to the presence of such functional compounds, Fucus spp. have been seen as potential functional and/or active ingredients with great interest and applicability not only in the cosmetic and pharmaceutical industries but also in the food and nutraceutical industries [18]. Indeed, the development of novel and improved foods containing seaweeds and/or seaweed-derived components is already a reality that is showing promising results, mainly in the field of dayries and seafoods [19-22].

In this context, the present manuscript reviews relevant studies on the nutritional and phytochemical composition of Fucus spp., highlighting the health benefits of its consumption and the main claimed benefic effects of their major bioactive metabolites. Additionally, the use of whole 
Fucus seaweeds and/or their components as functional ingredients for the development of novel and enhanced foods is discussed.

\section{Nutrient Composition of Fucus Spp.}

The moisture content of fresh Fucus spp. is very high, reaching up to $88 \%$ of the biomass (Table 1). The values are however lower than several other species such as Laminaria japonica or Porphyra yezoensis, which can reach $94 \%$ moisture content [23]. Similar to other seaweeds, Fucus spp. contain several nutritional elements important for human body's physiological functions [24]. However, the concentrations of such elements are very susceptible to seasonality, environmental conditions, geographical origin and several other factors making generalizations of algal composition very difficult.

Table 1. Moisture and macronutrients composition of different Fucus spp.

\begin{tabular}{cccccccc}
\hline Species & Moisture & Carbohydrates & Fiber & Protein & Lipid & Ash & Ref. \\
\hline F. serratus & $80-81$ & $26^{*}-62$ & 16 & $10-17$ & $0.4-3$ & $19-22$ & {$[25-29]$} \\
F. vesiculosus & $71-84$ & $34-66$ & $4-59$ & $1-11$ & $1.2-4$ & $23-36$ & {$[18,27,29-36]$} \\
F. spiralis & $82-88$ & $63 *$ & 63 & $10-11$ & $1.8-5$ & 22 & {$[12,24,37]$} \\
F. distichus & N.D. & N.D. & N.D. & N.D. & 3 & N.D. & {$[38]$} \\
Fucus spp. & $68-88$ & 26-66 & $4-63$ & $1-17$ & $0.4-5$ & $19-36$ & {$[2,20,39]$} \\
\hline
\end{tabular}

Values are expressed in \% DW. * calculated by a differential method subtracting (protein + lipid + ash) from total dry weight; N.D., no data found in the literature.

\subsection{Carbohydrates: Dietary Fiber and Polysaccharides}

Therefore, one should highlight that some data presented in Table 1 might provide the concentration as a snapshot and not consider the seasonal variations. Similar to other macroalgae, carbohydrates are the most abundant element of Fucus spp., serving different roles including storage, mucilage and structural functions [39]. Within this genus, the contents may vary from $26 \% \mathrm{DW}$, which was the lowest value registered in F. serratus, to $66 \%$ DW, as registered in F. vesiculosus (Table 1). This high content in carbohydrates does not correspond to high caloric values though, since most of these consist in dietary fibers, i.e., polysaccharides that are not digestible or absorbed in the human gastrointestinal tract [40]. Therefore, species from Fucus are a great source of dietary fiber that may play a relevant role for the improvement of human's gastrointestinal health by regulating the intestinal flow, stimulating the growth of favorable microbiota and preventing colon cancer [12]. Moreover, in combination with high glycemic foods, these fibers may reduce the glycemic response contributing for the regulation of the blood cholesterol and sugar, and ultimately preventing the development of obesity, diabetes, hypercholesterolemia and other related complications [41].

As the main constituents of Fucus dietary fiber, one can highlight three distinct polysaccharides, namely fucoidan, alginic acid and laminaran (Table 2), albeit their content is very susceptible to inter-species or even intra-species variations.

Table 2. Polysaccharide composition of Fucus species (\% DW). Adapted from [36,42-58].

\begin{tabular}{cccc}
\hline Species & Fucoidan & Alginic Acid & Laminaran \\
\hline F. vesiculosus & $3.4-25.7$ & $8.4-58.8$ & $0.6-7.0$ \\
F. serratus & $13.0-24.4$ & $10.5-22.2$ & $1.0-19.0$ \\
F. spiralis & N.D. & $13.0-16.6$ & $1.5-6.9$ \\
F. distichus & $14.6-21.5$ & $9.6-23.6$ & 2.2 \\
F. evanescens & $0.8-18.0$ & $0.3-20.0$ & $0.4-2.7$ \\
Fucus spp. & $0.8-25.7$ & $0.3-58.8$ & $0.4-19.0$ \\
\hline
\end{tabular}

Values expressed in \% DW; N.D., no data found in the literature. 


\subsubsection{Alginic Acid}

Regardless that variability, alginic acid is generally the most abundant of these polysaccharides, with values reaching up to 59\% DW in F. vesiculosus [53]. These polysaccharides are normally present in the structure of the cell walls where they play an important structural role, contributing for algae flexibility. Therefore, the more exposed seaweeds are to waves and turbulent conditions, the greater their alginic acid production [59]. Furthermore, concentrations of alginic acid in F. vesicuslosus, F. serratus and F. distichus were found to be $2-3$ times higher in the summer $(23.97 \%, 21.80 \%$ and $20.60 \%$ DW, respectively) than in the spring $(8.40 \%, 10.45 \%$ and $9.55 \% \mathrm{DW}$, respectively), indicating that the accumulation of these polysaccharides in this genus is highly dependent on seasonality [42].

In terms of structure, alginates are polyuronic saccharides consisting essentially of $\beta$-D-mannuronic $(\mathrm{M})$ and $\alpha$-L-glucuronic $(\mathrm{G})$ acid units linked together by $(1 \rightarrow 4)$ bonds, arranged in heteropolymeric (MG) and/or homopolymeric ( $M$ or $\mathrm{G}$ ) (Figure 2A). The mannuronic acid residues establish $\beta-(1 \rightarrow 4)$ linkages that confer a linear and flexible conformation to the M-block segments, whereas guluronic acid forms $\alpha-(1 \rightarrow 4)$ linkages that cause G-block segments to have a folded and rigid structural conformation, granting the polymer of a pronounced stiffness [60]. Moreover, in the presence of divalent ions such as $\mathrm{Ca}^{2+}$, G-blocks form "egg-box" junctions, allowing the bridging of two antiparallel chains and conferring gel-forming properties to alginates. Therefore, the length of G-blocks in this polysaccharide is determinant for the mechanical and functional properties of the gels [61].
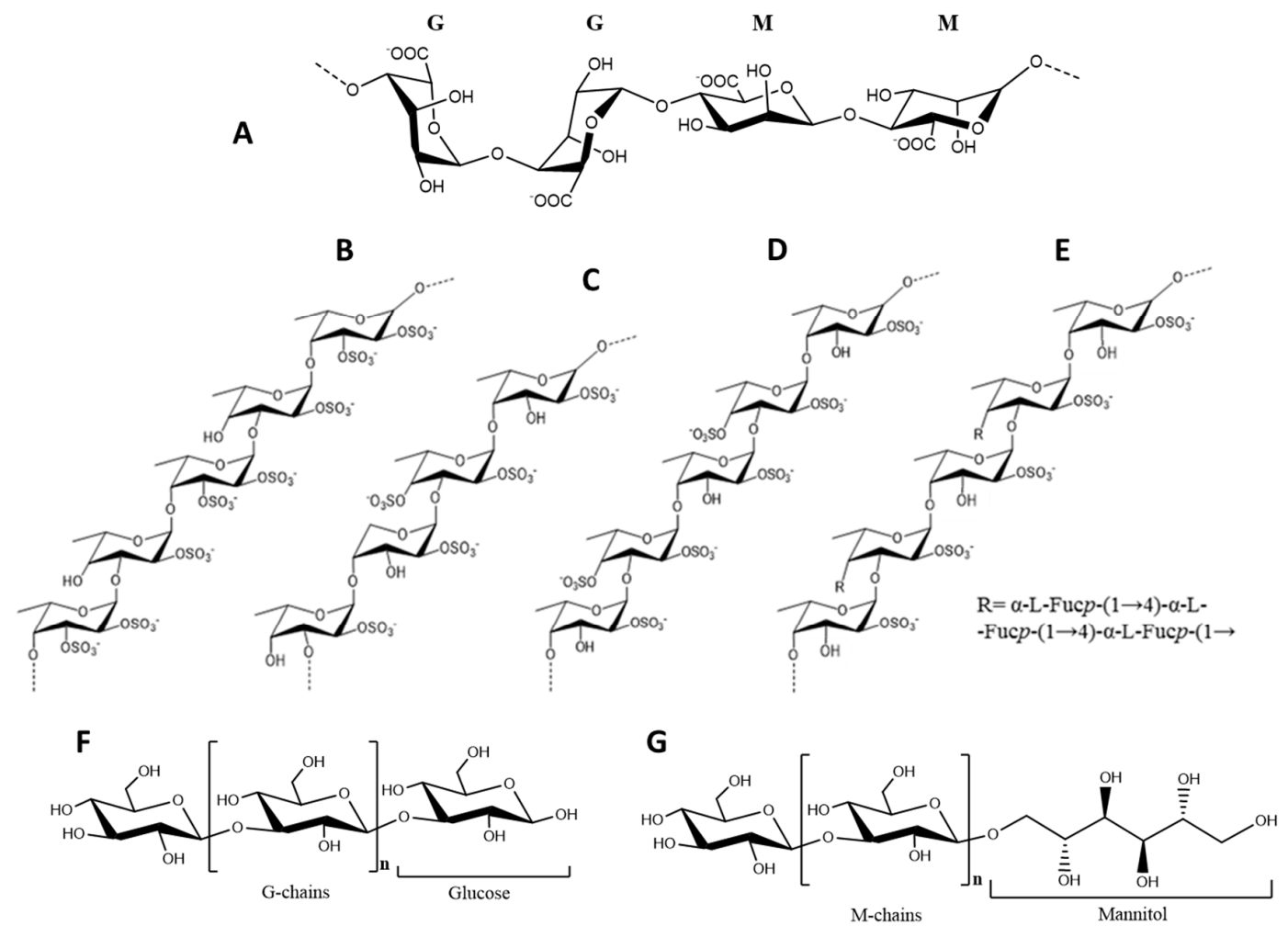

Figure 2. Representative chemical structures of the three main polysaccharides from Fucus: (A) alginic acid; (B-E) fucoidans from F. vesiculosus, F. evanescens, F. distichus and F. serratus, respectively (without representation of acetate groups); (F) G-laminaran; and (G) M-laminaran. Structures redrawn from [3].

Due to their excellent gel properties, as well as stabilizing and water-holding capacities, alginates have become a very important industrial product in several fields, including textile, material, cosmetic and medical/pharmaceutical, but above all, in food industry where it is mostly used as thickeners, gels, emulsifiers and stabilizers for improving the textural quality of several products such as salad 
dressings, ice-creams, beers, jellies, lactic drinks and many others [62]. Furthermore, due to their remarkable chelating abilities, biocompatibility, biodegradability and non-antigenicity a growing interest has recently emerged to use these polysaccharides in a multiple biomedical applications [63].

Dietary alginates have been recognized to have a number of potentially beneficial physiological effects in the gastrointestinal tract, contributing for the regulation of the intestinal flow while stimulating the growth of favorable microbiota [41]. Moreover, alginates have the capacity to adsorb a wide range of potential food and chemical mutagens, thereby not only lowering colonic exposure to these agents, but also preventing their absorption into the blood circulation [64,65]. Other common applications for alginates include the symptomatic treatment of heartburn and esophagitis [66], and appetite regulation through modulation of gastrointestinal signals that control hunger, satiety, and food intake $[67,68]$. Some clinical studies also demonstrated interesting antihyperglycemic and anti-hypercholesterolemic effects on patients administrated with alginic acid formulations, suggesting that consumption of alginates or alginate-rich foods might hold potential for the prevention and/or management of obesity, type 2 diabetes, cardiovascular disease and metabolic syndrome [69-73].

Alginates from Fucus spp., however, have low G-block ratios (22\%) and long M-blocks, giving them poor gel-forming capacity, thus producing low-strength gels [36,74]. These characteristics also greatly decreases the biological and chemical properties of Fucus alginates making them less interesting when comparing to others with high G-block content such as those from Laminaria hyperborean, Lessonia trabeculata or Saccharina latissima [75]. In addition, F. vesiculosus alginates are particularly sensitive to high temperatures and, according to Truus et al. [76], even a slight rise during the treatment of algal biomass led to a drastic fall in its viscosity. Therefore, algae from this genus are not the typical sources for alginate extraction.

\subsubsection{Fucoidans}

In turn, fucoidans are typically extracted from Fucus spp. where they also play an important structural role and a protective function against desiccation $[3,36]$. These polysaccharides are particularly abundant in F. vesiculosus, which can accumulate up to $26 \%$ DW (Table 2). Chemically, fucoidans are very complex polysaccharides, ranging from 100 to $1600 \mathrm{kDa}$, being composed mainly of fucose and sulfate, although other monosaccharides (mannose, galactose, glucose, xylose, etc.), uronic acids or even acetyl groups and proteins may be present $[77,78]$. Regardless, the high variability inherent to these polysaccharides, the structure of fucoidans typically consist of a backbone of $(1 \rightarrow 3)$ and $(1 \rightarrow 4)$-linked $\alpha$-L-fucopyranose residues, which can be separated in two types: type I consisting of long chains of $(1 \rightarrow 3)$-linked $\alpha$-L-fucopyranose residues and type II consisting of alternating $(1 \rightarrow 3)$ - and $(1 \rightarrow 4)$-linked $\alpha$-L-fucopyranose residues [15]. Fucoidans from Fucus spp. have a type II arrangement and are essentially composed of fucose and sulfate, although small amounts of other monosaccharides may occur.

Fucoidan from F. vesiculosus was firstly described as a linear chain of $(1 \rightarrow 2)$ - linked 4-O-sulfated fucose residues. However, further works have revised this structure and ultimately establishing it as a type II core motif with sulfation occurring at the position C-2 of the 3-linked fucose residues and positions C-2 and -3 of the 4-linked fucose residues (Figure 2B) [79].

Other structures have been reported for F. evanescens, F. distichus and F. serratus fucoidans. According to Bilan et al. [48] the fucoidan from the former has a type II backbone of L-fucose 2-sulfate residues, with additional sulfate and acetyl groups randomly occupying the C-4 positions of the 3-linked residues (Figure 2C). In turn, fucoidan from F. distichus consists of repeating units of alternating $\alpha-(1 \rightarrow 3)$ - and $\alpha-(1 \rightarrow 4)$-linked L-fucose 2,4-disulfate and only few acetylations in random positions of some residues (Figure 2D) [57]. From this group, only the fucoidan of F. serratus has a branched structure (Figure 2E). The backbone of this polysaccharide (also Type II) has half of the 3-linked residues substituted in the position C-4 by $\alpha-(1 \rightarrow 3)$ - and $\alpha-(1 \rightarrow 4)$-linked trifucoside units. Sulfate groups can be found mainly in position C-2 and occasionally C-4, although 3,4-diglycosylated and some terminal fucose residues might be non-sulfated. Acetylation may occur in the positions C-3 and C-4 of the 4- 
and 3-linked fucose residues, respectively. Traces of xylose and galactose may also be present [56]. Naturally, such variability is reflected by different biological potencies among these polysaccharides.

The ingestion of fucoidans from Fucus spp. origin have also been associated with several health benefits. Indeed, studies suggest that Fucus spp. fucoidans have potential to counteract oxidative stress and pro-inflammatory events, which are two interdependent pathophysiological processes responsible for the onset of numerous diseases. According to several authors, these polysaccharides may act as antioxidants either by directly scavenging reactive oxygen species such as hydroxyl $\left(\mathrm{OH}^{\bullet}\right)$, peroxyl $\left(\mathrm{ROO}^{\bullet}\right)$ and superoxide anion radicals $\left(\mathrm{O}_{2}^{\bullet-}\right)[43,80,81]$, or by stimulating the activity of cellular endogenous antioxidant defenses including superoxide dismutase (SOD), catalase (CAT), glutathione peroxidase (GSH-px), glutathione reductase (GSH-red), glutathione transferase (GSH-tr) and glucose-6-phosphate dehydrogenase [82]. Indeed, in LPS-stimulated BV2 microglial cells treated with $F$. vesiculosus fucoidan, the expression of several pro-inflammatory mediators including nitric oxide $\left(\mathrm{NO}^{\bullet}\right)$, prostaglandin $\mathrm{E}_{2}\left(\mathrm{PGE}_{2}\right)$ tumor necrosis factor- $\alpha$ (TNF- $\left.\alpha\right)$, interleukin- $1 \beta$ (IL-1 $\left.\beta\right)$, nitric oxide synthase (iNOS), cyclooxygenase-2 (COX) and monocyte chemoattractant protein-1 (MCP-1) were found dose-dependently decreased. Moreover, this polysaccharide exhibited promising inhibitory effects against important pro-inflammatory signaling pathways, through suppression of nuclear factor- $\mathrm{kB}(\mathrm{NF}-\mathrm{kB})$, protein kinase B (Akt), extracellular signal-regulated kinase (ERK), c-Jun $N$-terminal kinase (JNK), and p38 mitogen-activated protein kinase (p38-MAPK) [83].

The anti-inflammatory properties of dietary fucoidans were even demonstrated in some in vivo studies. According to Kuznetsova et al. [84], the serum levels of TNF- $\alpha$, IL-1 and IL-6 in LPS-injected $\mathrm{Balb} / \mathrm{c}$ mice were significantly reduced in the animals that have been orally administrated with $50 \mathrm{mg} / \mathrm{kg}$ body weight of F. evanescens fucoidan. Similarly, the expression of IL-6 was found decreased on colitis-induced Balb/c mice fed with F. vesiculosus fucoidan-enriched meals [85], while in a model of gastric ulceration, the oral administration of $20 \mathrm{mg} / \mathrm{kg}$ body weight of this polysaccharide to Wistar rats diminished the aspirin-induced up-regulation of plasma $\mathrm{PGE}_{2}$ and IL-6, and significantly increased the expression of the anti-inflammatory IL-10 [86]. The levels of transforming growth factor $\beta 1$ (TGF- $\beta 1$ ), COX-2 and $\mathrm{NO}^{\bullet}$ were also found lowered in the livers of fucoidan-fed alcoholic Balb/c mice compared to control animals [87].

More recently, a randomized controlled trial conducted with 122 patients suffering from osteoarthritis revealed that the daily intake of $300 \mathrm{mg}$ of $F$. vesiculosus fucoidan for a 12-week period resulted in approximately $30 \%$ improvement of the patients' knee joints. However, when compared to the placebo group, no significant differences were observed, which leads to inconclusive findings regarding to the possible fucoidan therapeutic effects for this chronic-inflammatory disease [88]. Nevertheless, a previous study, also carried out in osteoarthritis patients, revealed that the oral administration of Maritech, i.e., a commercial formulation composed of fucoidan-rich extracts from F. vesiculosus $(85 \% w / w)$, Macrocystis pyrifera $(10 \% w / w)$ and Laminaria japonica $(5 \% w / w)$, over 12 weeks, significantly decreased the pain, stiffness, difficulty with physical activity and overall symptom severity in a dose-dependent manner [89]. Taking these data together, it is possible to suggest that a diet including fucoidan-rich foods may help prevent or attenuate inflammatory-related complications such as septicemia, intestinal bowel disease, alcoholic cirrhosis or osteoarthritis.

Promising anti-diabetic properties have also been reported for Fucus spp. fucoidans which have been described to exert acarbose-like properties due to their capacity to inhibit $\alpha$-amylase and $\alpha$-glucosidase activities, hence reducing the absorption of glucose into the bloodstream $[90,91]$. Additionally, fucoidan from $F$. vesiculosus was shown to increase the expression of GLUT-4, PPAR- $\gamma$ and C/EBP $\alpha$ in 3T3-L1 adipocytes thus enhancing their sensitivity to insulin [92]. The anti-diabetic effects were also verified in vivo by different authors. In this context, Shan et al. [93] demonstrated that the oral administration of F. vesiculosus fucoidan decreased the fasting blood glucose and glycosylated hemoglobin levels of $\mathrm{db} / \mathrm{db}$ mice [91]. In turn, feeding Goto-Kakizaki (GK) rats with fucoidan from this species caused the reduction of the post-prandial blood glucose while raising the serum levels of insulin. 
Anticoagulant and antitumor activities are two additional very well documented properties of fucoidans. Several in vitro studies have shown that fucoidans obtained from different species, including F. vesiculosus, F. spiralis, F. serratus, F. distichus and F. evanescens, displayed identical anticoagulant properties to that of heparin, i.e., a commercial animal-derived sulfated polysaccharide currently used as an anticoagulant drug, which are mainly mediated via activation of plasma antithrombin-III and inhibition of thrombin, heparin cofactor II and coagulation factor Xa [94-97]. Indeed, some in vivo studies have already shown promising results regarding the anticoagulant activity of Fucus spp. fucoidans [17,97]. However, none have been carried out using the oral administration as the delivery route, meaning that further investigation is necessary to understand weather dietary fucoidans can or not exert these effects in vivo.

As an antitumor agent, fucoidans may trigger one or multiple pathways depending on the target cancer cell lines. For example, in vitro antiproliferative effect of $F$. vesiculosus fucoidan towards melanoma B16 cells or human lymphoma HS-Sultan cells was shown to result from the triggering of caspase 3 [98,99], while on MCF-7 breast cancer cells, HeLa cervical epithelioid cells and HT-29 human colon cancer cells, apoptotic chain reaction was initiated by activation of caspases 8 and/or 9 [100-102]. In A549 lung carcinoma cells and Raji cells, F. vesiculosus fucoidan was found to suppress the expression of matrix metalloproteinase 2 and 9, respectively [103,104], while fucoidans from F. serratus, F. distichus, and $F$. vesiculosus were shown to block the formation of platelet-tumor aggregates, i.e., a mechanism of tumor cells transportation and fixation in the metastatic site, of a highly metastatic MDA-MB-231 breast cancer cells [96], thus preventing the tumor dissemination and metastization. Additionally, as Fucus spp. fucoidans were found capable of preventing human umbilical vascular endothelial cells (HUVEC) from entering in tubulogenesis (formation of capillary structures) [96] and even inhibit their vascular endothelium growth factor (VEGF)-induced proliferation, it is possible to suggest that these polysaccharides may also hold antiangiogenic potential [105].

Both anticoagulant and antitumor activities of fucoidans have been shown to be highly dependent of their structural features, particularly degree of polymerization (DP) or degree of sulfonation (DS) [106]. Indeed, it has been recently shown that the depolymerization of F. vesiculosus fucoidans progressively hampered their anticoagulant activity. Previous studies also showed that the anticoagulant properties of $F$. vesiculosus fucoidans was best for a DP above 200 units while procoagulant activity was observed for DP below 70 units [107]. Likewise, according to Cumashi et al. [96], the anticoagulant activities of F. evansecens, F. serratus and F. distichus were much lower compared with those of $F$. vesiculosus and $F$. spiralis, which had substantially lower DSs compared to the other three $(29.2-36.3 \% w / w$ against $23.6-25.9 \% w / w$, respectively). Supporting these results, further research demonstrated that desulfonation of $F$. vesiculosus fucoidans caused a negative impact on their anticoagulant activity [108]. On the other hand, the oversulfonation of fucoidan was shown to increase the anticoagulant activity in relation to its native form [77].

In turn, lower molecular weights seem to increase the antitumor effects of fucoidans. In this field, depolymerized $F$. vesiculosus fucoidans with 7-16 kDa revealed significantly higher cytotoxicity towards human stomach, human breast and human hepatocellular cancer cell lines and inhibition of TPA-induced neoplastic cell transformation than their native forms (with $217 \mathrm{kDa}$ ) [109]. Similar results have been reported for low molecular weight fucoidans from other seaweeds [110]. In fact, an in vivo study has already been carried out revealing that the combination of cyclophosphamide with medium molecular weight (20-40 kDa) fucoidan from F. evanescens significantly inhibits the number of metastases in C57BL/ 6 mice transplanted with Lewis lung carcinoma comparing to the administration of the drug alone [111]. In turn, native F. evanescens fucoidan but not their low molecular weight fragments exhibited anticancer activities in both human malignant melanoma cell lines SK-MEL-28 and SK-MEL-5, which was attributed to the lower sulfonation degree of the low molecular weight fragments compared to the native fucoidan [112]. Indeed, the treatment of B16 melanoma cells, Sarcoma-180 and Lewis lung carcinoma cells with oversulfonated fucoidans from F. vesiculosus revealed better anti-proliferative effect than the treatment with native fucoidans, thus emphasizing the importance of 
this structural feature for the antitumor activity of these polysaccharides [15].Imunomodulatory [113] anticomplementary [114] or anti-angiogenetic [115] activity are examples of other bioactivities described for fucoidans for which molecular weight and sulfonation degree have been shown to be determinant.

Upon ingestion of fucoidan-rich foods, the cells that will be directly exposed to these polysaccharides are those of the gastrointestinal tract. Therefore, it is more likely that the antitumor activity of fucoidans will be further pronounced in these cells. Several authors reported effective antiproliferative activity of $F$. vesiculosus fucoidan against different human colon and stomach cell lines including HT-29, HCT-15 and HCT-116 human colon cancer cells, and MKN45 and Hs6 77.st human stomach cell lines [102,116,117]. Moreover, Vishchuk et al. [118] showed that the oral administration of different concentrations of $F$. evanescens fucoidan to xenograft mice models implanted with HCT-116 cells caused a significant dose-dependent inhibition of the tumor growth up to $72 \%$. According to the authors, this chemopreventive effect was associated to the inhibition of the phosphorylation of ERK $_{1 / 2}$ and histone $\mathrm{H} 3$, which are direct downstream signaling targets of lymphokine-activated killer T-cell-originated protein kinase (TOPK), that in turn is highly up-regulated in many cancers such as lymphoma, leukemia, melanoma, colorectal, breast, lung cancer, and cholangiocarcinoma. Additional in vivo studies carried out in different models of colon, hepatocellular, sarcoma and leukemia cancer cells have also described positive effects for oral ingestion of fucoidans, although these were not from Fucus spp. origin [119-121].

Anti-viral activity is another well-documented property of fucoidans. Indeed, as Ahmadi et al. [122] reviewed, fucoidans were shown to possess a remarkable capacity to inhibit a broad spectrum of viruses including poliovirus III, adenovirus III, ECHO6 virus, herpes simplex virus (HSV), citomegalovirus (CMV), dengue virus and even human immunodeficiency virus (HIV). However, many of those studies have been carried out using fucoidans from species non-related to the genus Fucus. Nevertheless, Queiroz et al. [123] showed pronounced in vitro anti-HIV activity for F. vesiculosus fucoidan which was closely related to its sulfonation degree. More recently, fucoidan extracted from F. vesiculosus has been tested against HSV-1 showing potent antiviral activity for the fucoidan fraction with the highest sulfate content [124]. Moreover, treatment of HBV-transfected hepatocytes with F. vesiculosus fucoidan showed a dose-dependent inhibitory effect on the virus DNA replicative intermediates through enhancement of ERK pathway and type I interferon response activation. These anti-HBV effects were further corroborated in vivo on HBV-infected mice models. However, the route used in this study for fucoidan administration was through intraperitoneal injection, thus further work is necessary to improve the understanding of the potential anti-HBV effect of these polysaccharides upon oral ingestion [125]. In this sense, to better comprehend the pharmacokinetic and tissue distribution of orally ingested fucoidan, Pozharitskaya et al. [126] has recently performed for the first time a study in which single-dose of $100 \mathrm{mg} / \mathrm{kg}$ body weight of F. vesiculosus fucoidan was supplied to male Wistar rats via intragastrical administration. According to their observations, the accumulation of fucoidan occurs preferentially in kidneys with a maximum concentration $\left(\mathrm{C}_{\max }\right)=1.23 \mu \mathrm{g} / \mathrm{g}$ (after $5 \mathrm{~h}$ ) and tissue availability $\left(\mathrm{f}_{\mathrm{t}}\right)=10.85$, followed by spleen $\left(C_{\max }=0.78 \mu \mathrm{g} / \mathrm{g}\right.$ after $3 \mathrm{~h}$ and $\left.\mathrm{f}_{\mathrm{t}}=6.96\right)$ and liver $\left(C_{\max }=0.53 \mu \mathrm{g} / \mathrm{g}\right.$ after $2 \mathrm{~h}$ and $\mathrm{f}_{t}=3.29$ ), showing a relatively long absorption time and extended circulation in the blood, with a mean residence time (MRT) of $6.79 \mathrm{~h}$.

Other less documented benefits described for Fucus spp. fucoidans include anti-obesity [92], anti-photoaging $[127,128]$ and antibacterial $[129,130]$.

\subsubsection{Laminarans}

Laminarans are algal glucans that serve as reserve compounds. Although these are characteristic from Laminariales (up to 33\% DW) [39], considerably high amounts of such polysaccharides can also be found in Fucales. In fact, F. serratus has been described as the non-Laminaria species with the highest content in these polysaccharides, which can amount up to 19\% DW [131]. These glucans consist of small linear polysaccharides with an average molecular weight of $5 \mathrm{kDa}$ built up of 20-50 glucose 


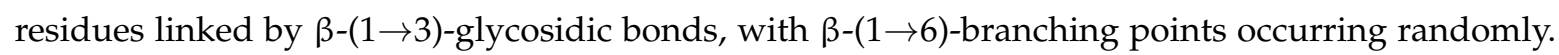
Laminarans can be classified in two types depending on their polymeric chain, i.e., G-laminarans, containing only glucose residues, and M-laminarans containing a D-mannitol residue at the terminal reducing end (Figure 2F,G) [132]. In addition, according to these polymeric types and particularly the ramification degree, laminarans may occur in soluble or insoluble forms, the former totally soluble in cold water and the later only in hot water. Higher ramification degrees normally correspond to better solubility [133]. Variations in the structures of these polysaccharides are also observable from species to species, differing in terms of molecular weight, branching degree and M:G ratio [134].

Since these polysaccharides do not form viscous solutions nor gels, their applications in an industrial scale is still very limited [131]. Nevertheless, commercial interest of laminarans (or derivatives) is emerging due to their interesting bioactivities, such as antioxidant, antitumor, antimicrobial, immunomodulation and anticoagulant properties, that have recently been reported in literature, thus indicating that these polysaccharides might have promising potential to be used with medical/pharmaceutical purposes [39,135-137].

The number of works focusing the bioactivities of Fucus laminarans is, however, very limited until the moment. Still, a laminaran fraction extracted from F. evanescens was shown to possess mild antioxidant activity, exhibiting a total antioxidant capacity of 51 ascorbic acid equivalents/g DW [43]. More recently, Malyarenko et al. [44] reported that among three different laminarans isolated from Saccharina cichorioides, Saccharina japonica and F. evanescens, the later displayed the strongest antitumor activities against human colorectal adenocarcinoma, melanoma, and breast adenocarcinoma cells, showing $35-50 \%$ inhibition of cell proliferation, 35-60\% inhibition of colony formation and $40-86 \%$ inhibition of cell migration at $200 \mu \mathrm{g} / \mathrm{mL}$. Furthermore, the authors also noticed that higher inhibitory percentages could be achieved if sulfated derivatives of $F$. evanescens laminaran were used instead of the native form. Either forms revealed high antitumor activity against breast adenocarcinoma cells, followed by colorectal adenocarcinoma and melanoma, suggesting that $F$. evanescens laminaran and/or sulfated derivatives might be particular effective if used in breast cancer therapies [44]. Studies with laminarans extracted from other algal also pointed out the potential of these polysaccharides to act as antitumor agents $[136,138]$. Nevertheless, these are still very preliminary studies and further research is required in order to clarify whether dietary laminarans display such bioactivities.

\subsection{Proteins and Amino Acids}

The protein fraction of brown seaweeds is generally low and very susceptible to seasonality, with the highest contents being observed at the end of winter and during the spring period [139]. Among Fucus spp., F. serratus is the species that has shown the maximal protein content of $17 \%$ DW, while F. vesiculosus and F. spiralis accumulate up to $11 \%$ of protein (Table 1). These values are substantially low when compared to red and green algae (up to $44 \% \mathrm{DW}$ ) or even other genus of brown algae such as Undaria, for which protein content has been described to reach up to 24\% DW [39]. Nevertheless, it is still high when compared to raw peas or fava beans (6.4\% and 7.4\% DW, respectively) which are commonly considered to be high vegetable protein suppliers [140].

The amino acids profile is also an important aspect to be considered since each individual amino acid may represent different roles in the organism. For example, aspartic acid and glycine are responsible for the formation of new tissues and regulations of the nervous system, while lysin and isoleucine are important for the immunologic system and phenylalanine for the thyroid function [141]. The most prevalent amino acids in Fucus spp. are undoubtedly aspartic and glutamic acids (Table 3) which according to Munda [142] may represent $22-44 \%$ of the total amino acids in the genus. The high content of glutamic acid is actually very important for the development of the special flavor and taste of seaweeds since this amino acid is the main responsible for the taste sensation of umami [143]. Alanine has also been seen in representative abundance in F. evanescens ethanolic extracts [144].

Moreover, seaweeds belonging to this genus contain all nine essential amino acids. The total content of these amino acids varies between $35 \%$ and $63 \%$ of total amino acids in F. vesiculosus and 
F. spiralis, respectively [24,142]. Threonine and valine, are abundant in F. spiralis, leucine in F. vesiculosus and F. serratus, and lysine in F. serratus. Together, these four amino acids represent the most abundant essential amino acids in Fucus spp., while the most limiting ones are methionine (except in F. spiralis), histidine and phenylalanine (Table 3). Few studies have documented the amino acid profile of different Fucus spp. which is resumed in Table 3. However, note that the amino acid content is very susceptible to seasonal variations, environmental conditions and other factors which are not contemplated in this table.

Table 3. Amino acid composition of different Fucus species. Adapted from [142,144-146].

\begin{tabular}{|c|c|c|c|c|c|c|}
\hline Aminoacid $^{a}$ & F. vesiculosus & F. ceranoides & F. spiralis & F. serratus & F. evanescens ${ }^{b}$ & Fucus spp. ${ }^{c}$ \\
\hline \multicolumn{7}{|l|}{ EAA } \\
\hline Thr & $3.91-4.72$ & 3.82 & 5.97 & 2.38 & 2.20 & $2.38-5.97$ \\
\hline Val & $3.98-4.49$ & 3.54 & 6.50 & 5.96 & 1.80 & $3.54-6.50$ \\
\hline Met & $1.39-1.74$ & 0.74 & 4.78 & 0.17 & N.D. & $0.17-4.78$ \\
\hline Ile & $3.06-3.91$ & 2.77 & 4.49 & 4.48 & N.D. & $2.77-4.49$ \\
\hline Leu & $5.60-6.64$ & 4.80 & 4.19 & 7.78 & 1.80 & $4.19-7.78$ \\
\hline Phe & $3.25-4.17$ & 2.99 & 2.78 & 3.86 & 3.50 & $2.78-3.90$ \\
\hline Lys & $3.95-6.16$ & 3.54 & 4.96 & 5.85 & 1.50 & $4.08-5.85$ \\
\hline His & $1.36-1.70$ & 1.24 & 1.89 & 1.48 & N.D. & $1.24-1.89$ \\
\hline \multicolumn{7}{|l|}{ NEAA } \\
\hline Asp & $7.98-12.91$ & 9.88 & 12.05 & 13.85 & 4.50 & $7.98-13.85$ \\
\hline Ser & $3.76-4.85$ & 3.58 & 6.79 & 5.96 & 1.20 & $3.58-6.79$ \\
\hline Glu & $9.10-24.28$ & 31.47 & 16.30 & 24.46 & 26.00 & $9.10-31.47$ \\
\hline Pro & $3.33-4.43$ & 2.76 & 3.01 & & 5.00 & $2.76-3.71$ \\
\hline Gly & $4.06-5.01$ & 3.63 & 10.16 & 6.75 & 2.20 & $3.63-10.16$ \\
\hline Ala & $4.93-7.59$ & 6.08 & 11.05 & 11.58 & 32.00 & $4.93-11.58$ \\
\hline Tyr & $1.50-2.52$ & 2.99 & 1.36 & 1.42 & 2.50 & $1.36-2.14$ \\
\hline Arg & $4.38-4.56$ & 3.94 & 1.59 & 2.95 & 2.00 & $1.59-4.56$ \\
\hline
\end{tabular}

Values are expressed as $\mathrm{g} / 100 \mathrm{~g}$ protein. ${ }^{\mathrm{a}}$ Trp and Cys are missing from this table because methods used by the authors do not allow to analyze the contents of these two amino acids. ${ }^{b}$ Values for F. evanescens are expressed in $\%$ DW. ${ }^{c}$ Range values in Fucus spp. column do not contemplate the values of F. evanescens. EAA, essential amino acids; NEAA, non-essential amino acids, N.D., no data found in the literature.

Recently, Paiva and co-workers [24] have reported an amino acid profile for F. spiralis that do not fit within the patterns above mentioned. In their work, glutamic acid was found in high abundance but not as the most abundant amino acid. Instead, leucine and isoleucine were the amino acids with higher prevalence, both accounting for about $20 \%$ of the total amino acids fraction. Other amino acids such as serine, proline arginine, threonine, valine and lysine were also found in relevant concentrations.

\subsection{Lipids and Fatty Acid Profile}

Total lipid content in seaweeds is generally low, reaching up to $6 \% \mathrm{DW}$, which in a practical sense makes their contribution as food energy sources negligible [147]. The total lipid content in Fucus spp. ranges $0.4-5 \% \mathrm{DW}$, fitting in the aforementioned values (Table 1). F. spiralis was the species for which the highest lipid content was reported (5\% DW) [24], while the lowest value was observed in F. serratus $(0.4 \% \mathrm{DW})$ [28]. Note that, similarly to other biochemical components, the total lipid content of Fucus spp. may vary according to the season, environmental conditions, genetic differences and several other factors. In fact, the total lipid content in seaweeds has been reported to be higher during the winter and spring, and lower during the summer [148]. Nevertheless, F. serratus does not seem to fall within this pattern since its lipid content was reported to be higher in the summer [28]. Similar observations have been recently reported by Schmid et al. [149], who observed that the total lipid content in F. vesiculosus and F. serratus is higher in August rather than in November.

Although they are low in fat, many authors have focused their studies in the lipid fraction of Fucus spp. due to the high content in polyunsaturated fatty acids (PUFAs) (Table 4), which are essential fatty acids of the utmost importance for human metabolism [150]. Since these fatty acids are not synthesized by mammals, they can only be introduced in our organism through diet [151]. 
From the reported studies, it is possible to conclude that the total content of PUFAs in Fucus spp. ranges between $24 \%$ and $48.5 \%$ of total fatty acids (TFA), with particular emphasis on F. distichus which is at the top of the list for about $10 \%$ more PUFA content than the remaining species. On the other hand, the total content of saturated fatty acids (SFAs) is maximum in F. spiralis reaching up to $53 \%$ TFA, while the amounts in other species range from $24 \%$ to $35 \%$ TFA. In contrast, $F$. spiralis is also the one with the lowest content in monounsaturated fatty acids (MUFAs) together with F. distichus (15.4-27.1\% and $18.5 \%$ TFA, respectively).

Table 4. Fatty acid profile of different Fucus species. Adapted from [24,28,37,38,149,152-156].

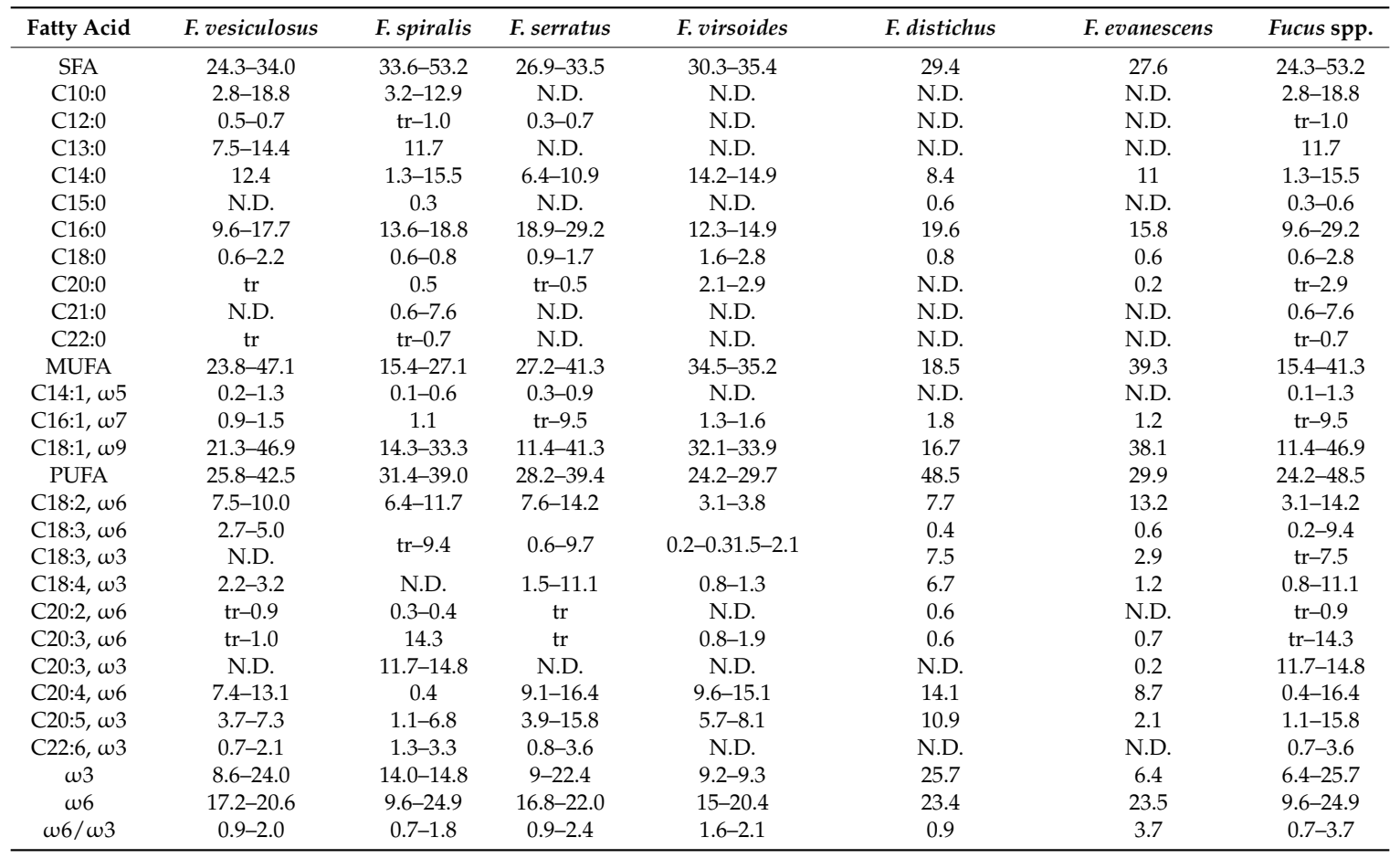

Values expressed in percent of total fatty acid. SFA, saturated fatty acids; MUFA, monounsaturated fatty acids; PUFA, polyunsaturated fatty acids; tr, trace; N.D., no data found in the literature.

The most abundant SFAs in the genus Fucus are palmitic (C16:0) followed by myristic (C14:0) acids, representing $9.6-19.6 \%$ and $1.3-15.5 \%$ of the TFA, respectively (Table 4). An exception to this is the palmitic acid content in F. serratus, which is substantially higher (up to 29\% TFA) [28]. On the other hand, oleic acid (C18:1, w9), not only is the major MUFA but also the major fatty acid of the genus reaching concentrations that may stand for almost $50 \%$ of the total fatty acids [155]. In fact, according to the review of Holdt and Kraan [39], Fucus spp. are among the marine macroalgae with the highest content on this fatty acid.

As mentioned before, PUFAs are of particular interest due to their favorable effects on human's health, especially when considering $\omega 3$ fatty acids. Note that $\omega 3$ fatty acids have been recognized to exhibit anti-inflammatory and antioxidant activities, which may contribute to their beneficial cardiac effects while most $\omega 6$ fatty acids (precursors of arachidonic acid and prostaglandin $\mathrm{E}_{2}$ ) tend to promote inflammation [157]. It is therefore important to maintain an appropriate balance between $\omega 6$ and $\omega 3$ in the diet to reduce the risk of developing several diseases and maintain a healthy state. According to Simopoulos et al. [158], the optimal ratio of $\omega 6 / \omega 3$ is 2-5:1, but, in the Western population, due to high consumption of refined oils rich in $\omega 6$, the actual ratio is 15-17:1.

Marine macroalgae are particularly abundant in $\omega 3$, which may represent up to $50 \%$ of their total fatty acids content [2]. In Fucus spp., the total content in $\omega 3$ ranges $6.4-25.7 \%$ which is not very different from the ranging concentrations of $\omega 6$ (9.6-24.9\% TFA; Table 4). Therefore, the ratios between 
$\omega 6$ and $\omega 3$ found in this genus (0.7-3.7) are within or lower than the optimal limits aforementioned. The most prevalent $\omega 3$ fatty acids are eicosapentoic $(\mathrm{C} 20: 5, \omega 3)$ and stearidonic $(\mathrm{C} 18: 4 \omega 3)$ acids, ranging $1.1-15.8 \%$ and $0.8-11.1 \%$ of TFA, respectively [28]. Eicosatrienoic acid (C20:3, $\omega 3)$ has also been reported in abundant concentrations (11.7-14.8\% TFA) but only in F. spiralis [24,37]. In contrast, arachidonic $(\mathrm{C} 20: 4, \omega 6)$ and linoleic $(\mathrm{C} 18: 2, \omega 6)$ acids are the dominant $\omega 6$ fatty acids of this genus, reaching up to $16.4 \%$ and $14.2 \%$ TFA, respectively [28]. Relevant amounts of dihomo- $\gamma$-linolenic $(14.3 \% ; \mathrm{C} 20: 3, \omega 6)$, an isomer of eicosatrienoic acid, were described also solely in F. spiralis [24].

In addition to fatty acids, the lipid fraction of Fucus spp. contains other interesting unsaponifiable compounds such as carotenoids, with special emphasis of fucoxanthin, which may range from 340 to $730 \mathrm{mg} / \mathrm{kg}$ DW [39]. Fucoxanthin has been described by several authors for its numerous interesting bioactivities with particular interest for application in nutraceutical and pharmaceutical fields. These properties will be discussed further in below.

\subsection{Minerals}

Algae content in minerals is generally high $(8-40 \%$ DW), mostly due to the characteristics of their cell surface polysaccharides that allow them to retain inorganic marine substances [2]. Nevertheless, the mineral content of seaweeds is very variable according to the geographic harvesting site, wave exposure, seasonality and even between species in the same phylum [159]. According to Rupérez [160], the mineral content in brown algae is higher than in Rhodophyta. In the particular case of Fucus spp., the ash (mineral) content may vary from 19\% to $36 \%$ DW (Table 1), which is substantially higher than the values found in terrestrial plants. Indeed, mean ash content of most common vegetables is much lower compared to that of Fucus spp. (e.g., 10.4\% DW in potatoes, $7.1 \% \mathrm{DW}$ in carrots and tomatoes, and 2.6\% DW in sweet corn) [3].

Similar to other seaweeds, Fucus spp. contains several important minerals including $\mathrm{Na}, \mathrm{K}, \mathrm{Ca}$, $\mathrm{Mg}, \mathrm{Fe}, \mathrm{Cu}, \mathrm{Zn}, \mathrm{Mn}$ and I [161]. Sodium and potassium are the major elements described in this genus, with concentrations ranging from 630 to 5469 and 976 to $4322 \mathrm{mg} / 100 \mathrm{~g}$ DW, respectively (Table 5). This represents up to eight times more sodium than cheddar cheese and 11 times more potassium than bananas [162]. However, despite these high levels, the $\mathrm{Na} / \mathrm{K}$ ratio is actually low (0.6-1.5). Note that intakes of high $\mathrm{Na} / \mathrm{K}$ ratios typical of modern Western diets are well known to be related with higher incidence of hypertension [163] and, therefore, products with low $\mathrm{Na} / \mathrm{K}$ ratios may help to regulate the dietary $\mathrm{Na} / \mathrm{K}$ imbalance. Indeed, this characteristic is one of the main advantages for the use of Fucus spp. and other seaweeds as foods.

Table 5. Major mineral and trace elements in different Fucus spp. Adapted from [24,154,160,164-168].

\begin{tabular}{cccccc}
\hline Element & F. vesiculosus & F. spiralis & F. serratus & F. guiryi & Fucus spp. \\
\hline $\mathrm{Na}$ & $630-5469$ & 1429 & 2305 & N.D. & $630-5469$ \\
$\mathrm{~K}$ & $1100-4322$ & 976 & 2490 & N.D. & $976-4322$ \\
$\mathrm{Ca}$ & $938-2150$ & $118-1049$ & $1284-2175$ & 895 & $118-2175$ \\
$\mathrm{Mg}$ & $740-994$ & $163-819$ & $724-844$ & 702 & $163-994$ \\
$\mathrm{Fe}$ & $4.2-49$ & 52 & 31 & 13 & $4.2-52$ \\
$\mathrm{Cu}$ & $0.2-1.4$ & 0.2 & $0.3-1.4$ & 0.2 & $0.2-1.4$ \\
$\mathrm{Zn}$ & $2.6-28$ & 15 & $5.3-29$ & 4.5 & $2.6-29$ \\
$\mathrm{Mn}$ & $3.4-6.6$ & 6.3 & $14-29$ & 11 & $3.4-29$ \\
$\mathrm{I}$ & $13-73$ & 23.3 & 32 & 27 & $13-73$ \\
$\mathrm{Na} / \mathrm{K}$ & $0.6-1.3$ & 1.5 & 0.9 & N.D. & $0.6-1.5$ \\
\hline
\end{tabular}

Data expressed in $\mathrm{mg} / 100 \mathrm{~g}$ DW. N.D., no data found in the literature.

Fucus spp. also contain levels of $\mathrm{Ca}$ and $\mathrm{Mg}$ in much higher concentrations than those found in common foods. As an example, according to Ross et al. [166], the values of Ca in F. serratus may reach the $2175 \mathrm{mg} / 100 \mathrm{~g}$ DW, which represents almost 20 times more the Ca present in $100 \mathrm{~g}$ of whole 
milk [162]. Regarding Mg, the highest concentrations were described for F. vesiculosus corresponding to $994 \mathrm{mg} / 100 \mathrm{~g}$ DW [160], which represents approximately five times more the levels present in peanuts [162]. Particularly high levels of Fe have been described in F. vesiculosus and F. spiralis (up to 49 and $52 \mathrm{mg} / 100 \mathrm{~g}$ DW, respectively), while F. serratus seems to be a good accumulator of Mn (Table 4).

Exceptionally high amounts of iodine can accumulated in brown algae, and Fucus are no exception. In fact, F. vesiculosus along with Laminaria sp. were the original sources of iodine, found in 1811 by Courtois [13]. The content of this mineral in Fucus spp. may vary between 13 to $73 \mathrm{mg} / 100 \mathrm{~g}$ DW, with the maximal concentration being described in F. vesiculosus [168]. Indeed, according to Moro and Basile [169], this element is the most important active principle of this species since it has an active role in the production of thyroid hormones which in turn are responsible for the increase of the metabolism in most tissues, and the consequent raise of the basal metabolic rate [13]. Because of that, $F$. vesiculosus supplements are commonly used not only for the treatment of obesity but also for treating iodine deficiency goiter [170]. Indeed, the market is currently full of numerous Fucus-based supplements and nutraceuticals including InSea2 ${ }^{\mathrm{TM}}$ (INNOVACTIV Inc., Rimouski, QC, Canada), Fucus Plus ${ }^{\circledR}$ (North America Pharmacal Inc., Wilton, CT, USA), ThyroMate ${ }^{\mathrm{TM}}$ (Vitus Laboratories, LLC., College Park, MD, USA), SeaVeg ${ }^{\circledR}$ (FarmaSea ${ }^{\circledR}$, Scottsdale, AZ, USA) among many others, which are recommended for the treatment of these two complications. However, the consumption of such supplements must have some precautions since the daily intake of more than $600 \mu \mathrm{g}$ of iodine (tolerable upper intake level for adults) may result in poisoning effects [171]. Nevertheless, considering that iodine deficiency is a reality at least in 11 European countries and most of the remaining countries are using iodized salts to control this problem, the introduction of Fucus spp. in population eating habits could be a valid alternative to ensure the intake of the optimal daily requirement of iodine and hence, a proper thyroid function [172].

The high bioaccumulative capacity of brown seaweeds may also be their worst disadvantage as the concentrations of heavy metals can reach toxic levels. This is particularly true for Fucus spp. since these belong to the Fucacea which is one of the most important biosorbent families from Phaeophyta [173]. Because of their inability to regulate the concentration of heavy metals in their tissues and also due to their tolerance to high external levels of such pollutants, seaweeds from this genus have been commonly used as bioindicators and bioremediators of heavy metal contaminated waters [174,175]. According to several authors, the content of $\mathrm{As}, \mathrm{Pb}, \mathrm{Cd}$ and $\mathrm{Hg}$ in F. vesiculosus growing in heavy metal contaminated waters may reach up to $73,12,10$ and $2 \mathrm{mg} / \mathrm{kg}$ DW, respectively [176-178], representing 52, 2, 5 and 4 times more than the maximum permitted concentrations established for each element [179]. There is, however, a relation between the toxic effect of the heavy metals and their physical state, especially for As, whose inorganic forms are much more toxic than the organic ones [180]. Studies have shown that many algae, including Fucus spp., are able to metabolize inorganic arsenic into organic forms, and although this genus is naturally prone to accumulate substantial levels of arsenic, this is found predominantly in its organic form [181-183]. Therefore, even though Fucus spp. might have high levels of As, it does not necessarily mean that its consumption will cause poisoning effects. Nevertheless, before the consumption of these algae, it is always necessary to ensure that they meet the appropriate criteria concerning the heavy metal composition.

\section{Other Nutritional Elements}

\subsection{Vitamins}

Seaweeds are also a wealthy source of a broad range of these micronutrients which include water- (vitamin C and those belonging to the complex B) and fat-soluble (vitamin A, D, E and K) vitamins [184]. In fact, according to Chapman and Chapman estimations, the consumption of only $100 \mathrm{~g}$ of seaweed provides more than the daily requirement of vitamin $\mathrm{A}, \mathrm{B}_{2}$ and $\mathrm{B}_{12}$ and two thirds of the vitamin C requirement [51]. 
Vitamins C and E (Figure 3A,B) are by far the most predominant in Fucus spp. The levels of vitamin C in F. vesiculosus are very variable, ranging from 141 to $770 \mathrm{mg} / \mathrm{kg}$ DW [185]. Such wide range of concentrations are a consequence of the variations in environmental conditions, geographical origin, light exposure, and, especially, seasonality. This has been demonstrated in different algal species including in $F$. vesiculosus and $F$. serratus, which exhibited minimum vitamin $C$ concentrations during the winter (13 and $11 \mathrm{mg} / 100 \mathrm{~g}$ fresh weight (FW), respectively), while maximum concentrations were observed in the summer (77 and $48 \mathrm{mg} / 100 \mathrm{~g}$ FW, respectively) [51]. This means that a portion of Fucus spp. may contain identical or even higher amounts of this micronutrient than oranges $(53 \mathrm{mg} /$ $100 \mathrm{~g}$ FW), which are the vitamin C-rich foods of excellence [184].

A<smiles>Cc1c(C)c2c(c(C)c1O)CC[C@@](C)(CCC[C@H](C)CCC[C@H](C)CCCC(C)C)O2</smiles><smiles>[2H]OC1OC(=O)C(O)=C1O</smiles><smiles>CC1=C(/C=C/C=C(C)/C=C/C=C(\C)CO)C(C)(C)CCC1</smiles>

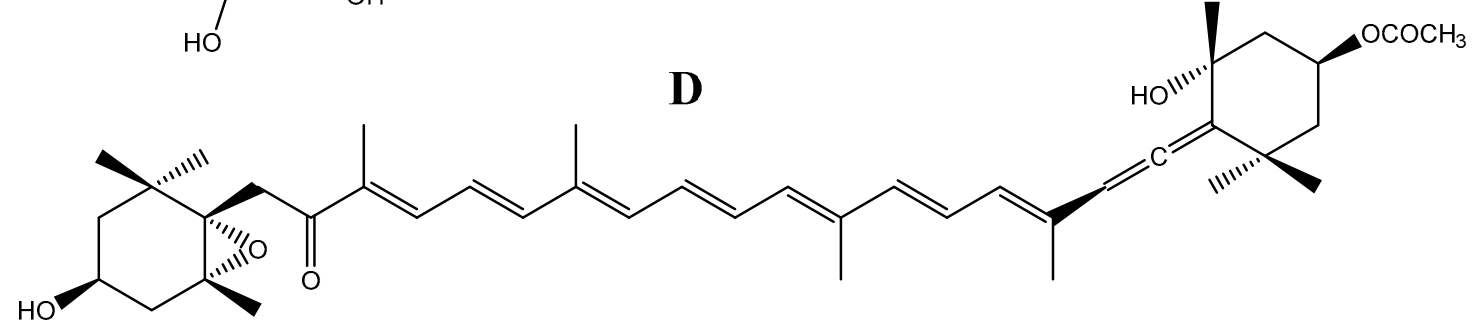

Figure 3. Representative chemical structure of: (A) vitamin E; (B) vitamin C; (C) vitamin A; and (D) fucoxanthin. Structures redrawn from [3,186-188]

The positive effects that this vitamin has on human's health have been extensively studied. It is believed that it may help to reduce the risk of cancers, regulate blood pressure and stimulate intestinal Fe absorption $[189,190]$, but the main physiological role of vitamin $\mathrm{C}$ is as an antioxidant agent, participating in the ascorbate-glutathione cycle to reduce $\mathrm{H}_{2} \mathrm{O}_{2}$ to water as well as directly scavenging ${ }^{1} \mathrm{O}_{2}, \mathrm{O}_{2}{ }^{\bullet-}$ and $\mathrm{OH}^{\bullet}$ [191]. Moreover, it also contributes for the recycling of tocopherol [192], which is another strong antioxidant vitamin involved in the prevention of lipid oxidation, protecting the membranes, fatty acids and lipoproteins from reacting with reactive oxygen species [193]. The levels of this vitamin in Fucus spp. may reach up to $600 \mathrm{mg} / \mathrm{kg}$ DW [194] making this genus one of the richest in vitamin E. F. serratus has been described as the species with the highest content in this micronutrient (600 mg/kg DW), followed by F. spiralis (511 mg/ $\mathrm{kg}$ DW) and F. vesiculosus ( $490 \mathrm{mg} / \mathrm{kg}$ DW) [24,194], presenting approximately four times more vitamin $\mathrm{E}$ than olive oil $(140 \mathrm{mg} / \mathrm{kg})$, which is considered the major source of tocopherol in European's diet [184]. Similar to other nutrients, vitamin $\mathrm{E}$ is strongly affected by seasonal fluctuations, however, unlike vitamin $\mathrm{C}$, the periods of higher accumulation of this vitamin coincide with autumn and early winter, while the lowest concentrations are observable in spring [24,194]. From the different forms of vitamin E, $\alpha-, \beta-, \delta$ and $\gamma$-tocopherols have all been described in Fucus spp., although $\alpha$-tocopherol is usually the dominant form found in these seaweeds $[24,195]$. This is an important detail considering that $\alpha$-tocopherol is the most 
active form of this vitamin [196]. Recently, it has been discovered that F. vesiculosus also contains trace amounts of three other vitamin E vitamers, namely $\alpha-, \delta$ and $\gamma$-tocotrienols [197].

The levels of retinal, i.e., vitamin A (Figure 3C), an essential vitamin for the promotion of general growth, maintenance of visual function, regulation of differentiation of epithelial tissues, and embryonic development [198], are quite low in the genus Fucus, being described to reach up $14.1 \mathrm{mg} / \mathrm{kg}$ DW in F. spiralis and even less in F. vesiculosus (3.1 mg/kg DW) [14,24]. Nevertheless, this genus is endowed with considerable high amounts of $\beta$-carotene (provitamin A), which can be converted in retinal by the intestinal enzyme $\beta$-carotene $15,1^{\prime}$-monooxygenase [199]. The abundance of this carotenoid in Fucus seems to be maximum in F. evanescens, accounting for $32.1 \mathrm{mg} / \mathrm{kg}$ fresh weight, followed by F. distichus (21.3 mg/ $\mathrm{kg} \mathrm{FW)} \mathrm{and} \mathrm{F.} \mathrm{spiralis} \mathrm{(6.9} \mathrm{mg/kg} \mathrm{FW)} \mathrm{[200].} \mathrm{In} \mathrm{F.} \mathrm{vesiculosus}$ and F. serratus, the content of provitamin A may range 80-95 and 80-173 mg/kg DW, respectively [39]. Other vitamins including vitamin $\mathrm{D}, \mathrm{K}$, and some of the B-complex have also been described in Fucus spp., however, they have only been found in trace amounts $[11,24]$.

\subsection{Fucoxanthin}

Fucoxanthin is the major carotenoid produced by brown algae and the main responsible for their brownish color [201]. This pigment belongs to the class of xanthophylls, possessing a unique structure, that includes an allenic bond, an epoxide and a conjugated carbonyl group in the polyene chain of the molecule (Figure 3D). Fucoxanthin may exist in trans- and cis-configurations, although the former is thermodynamically more stable than the latter [202].

According to Haugan et al. [203], approximately $70 \%$ of the total carotenoid content in F. serratus corresponds to fucoxanthin. Identical contents were further described either in F. serratus and F. vesiculosus [204]. Nevertheless, the content of this pigment in Fucus varies greatly from species to species and depending on the life cycle and environmental conditions. For instance, in F. spiralis, fucoxanthin accounts only for $171 \mathrm{mg} / \mathrm{kg}$ FW, while concentrations of 224 and $364 \mathrm{mg} / \mathrm{kg}$ FW were observed in F. distichus and F. evanescens, respectively [200]. Ramus et al. [205] reported concentrations up to $751 \mathrm{mg} / \mathrm{kg}$ FW in F. vesiculosus collected from shaded intertidal zones, which is much higher than the concentrations of other fucoxanthin-rich seaweeds including A. nodosum (172-660 mg/kg) or Laminaria spp. (178-468 mg/kg) [39]. However, these values dropped for $247 \mathrm{mg} / \mathrm{kg}$ FW in seaweeds growing in more sunny areas, representing a decrease of almost $70 \%$ in the fucoxanthin content. In addition to light exposure, these authors also observed that depth could be another determinant factor in the accumulation of this xanthophyll, since F. vesiculosus seaweeds growing at $4 \mathrm{~m}$ depth had $50 \%$ higher content in fucoxanthin than those growing in shallower areas.

This xanthophyll has earned particular attention in the recent years mainly because of its promising anti-obesity effects, since it has the capacity to reduce the expression of adipocyte marker proteins such as PPAR $\gamma$ and $\mathrm{C} / \mathrm{EBP} \alpha$, consequently inhibiting lipid uptake [206]. In addition, mRNA expressions of important lipid metabolism-related enzymes including hepatic acetyl-CoA carboxylase (ACC), fatty acid synthase (FAS), glucose-6-phosphate dehydrogenase (G6PDH), hydroxy-3-methylglutaryl coenzyme A (HMG-CoA), acyl-CoA cholesterol acyltransferase (ACAT), and SREBP-1C were found decreased in rats on a high fat diet supplemented with fucoxanthin [207]. Several other in vivo studies have shown that fucoxanthin may as well mediate plasma adipokine levels, down-regulating the lipogenic enzyme activities involved in fat production while up-regulating fatty acid $\beta$-oxidation activity and uncoupling protein gene expressions, thus stimulating metabolic thermogenesis and consequently contributing for the reduction of their body weight [208-211].

Fucoxanthin has also been reported to prevent oxidative stress-related lipid peroxidation and DNA damage through scavenging of intracellular ROS and enhancement of intracellular defenses by up-regulation of Nrf2/ARE signaling pathway and its down-stream phase II detoxification and anti-oxidant enzymes [212-216], to inhibit the expression of different pro-inflammatory mediators such

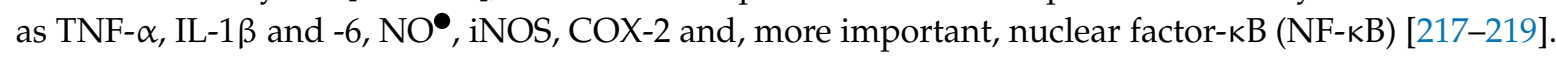
It may also exert antitumor activity either by stimulating apoptosis through activation of cytochrome $c$, 
cleavage of caspases 8, 9, 7 and 3 and inhibiting the expression of anti-apoptotic proteins such Bcl-Lx and Bcl-2 [220-222], or by activating cell cycle arrest through cytostatic activity and consequently blocking the tumor growth [223-225]. Other promising properties previously described for this pigment include anti-diabetes, anti-photoaging, anti-angiogenesis and anti-atherosclerosis effects [214].

Currently, fucoxanthin is considered safe by the European Food Safety Authority, Japan's Food for Specified Health Uses, and the US Food and Drug Administration and has already been incorporated as functional ingredient in food products and supplements. In turn, medical and health applications have only emerged during the recent years. However, mostly due to its oxidative instability and the prohibitive costs of inefficient extraction methods, the utilization of fucoxanthin in industry remains underexploited [226]. Nevertheless, world fucoxanthin production in 2015 was approximately $500 \mathrm{t}$ and it is expected to increase at least 5.3\% per annum between 2016 and 2021 [227].

\subsection{Phenolic Compounds (Phlorotannins)}

Phlorotanins are a group of marine exclusive phenolic compounds formed by polymerization of phloroglucinol (1,3,5-trihydroxybenzene) units, characteristically abundant in brown seaweeds. These are very hydrophilic compounds, biosynthesized through the acetate-malonate pathway, and their molecular weights vary between $126 \mathrm{Da}$ and $650 \mathrm{kDa}$ [228]. Depending on the nature of the structural linkages between phloroglucinol units and number of hydroxyl groups, phlorotannins can be grouped into fuhalols and phlorethols (possessing an ether linkage), fucols (possessing a phenyl linkage), fucophlorethols (possessing an ether and phenyl linkage), and eckols and carmalols (possessing a dibenzodioxin linkage) (Figure 4) [229]. From these, fucols and fucophlorethols are the predominant compounds found in Fucus spp. [230-234].

According to what Holdt and Kraan reviewed, the highest phlorotannin content recorded for a Fucus sp. was $12 \%$ DW [39]. However, the accumulation of phlorotannins in this genus may vary from species to species, as it was observed by Connan et al. [235], who reported that $F$. vesiculosus had the highest phlorotannin content (approximately $6 \%$ dry weight) compared to F. serratus and F. spiralis (4.3\% and 3.9\%, respectively). Furthermore, other factors such as seasonality, solar exposure or salinity may contribute as well for significant intra-species variations. Indeed, the phlorotannin concentrations of Fucus spp. have been reported to be higher during the summer [235] at higher salinity waters $[236,237]$ and solar exposure periods [238].

During the last few years, these compounds have gathered great interest since they have been shown to exert numerous biological activities with potential application in food, pharmaceutical and cosmetic industries, and others. As phenolic compounds, the antioxidant activity is the greatest potential of phlorotannins, with no exception for those from Fucus origin. Indeed, these have been described as having great capacity to scavenge different radicals [239-242], prevent oxidative stress-induced DNA damage and stimulate cellular antioxidant defenses [213,243]. Interestingly, although Wang et al. [242] previously reported that there was no evident correlation between antioxidant activity and the molecular weight of phlorotannins extracted from $F$. vesiculosus, it has been recently demonstrated that these are indeed correlated since the antioxidant activity of phlorotannins from this species tend to decrease with the increase of their degree of polymerization, thus indicating an inversely proportional correlation [244].

Phlorotannis extracted from Fucus spp. have also been described for their good anti-inflammatory effects by counteracting an array of pro-inflammatory mediators which include several cytokines such as IL-1 $\beta$, IL-6, IL-17 and TNF- $\alpha$, as well as chemokines such as monocyte chemoattractant protein-1 (MCP-1), macrophage inflammatory protein $2 \alpha$ (MIP- $2 \alpha)$, interferon gamma-induced protein 9 and 10 (IP-9 and -10), enzymes iNOS and COX-2, toll-like receptors 4 and 9, components of NF-KB, adhesion molecules and many others [213,245-247]; and good antidiabetic effects, exhibiting acarbose-like activity, i.e., acting as $\alpha$-amylase and $\alpha$-glucosidase inhibitors and consequently reducing the polysaccharides breakdown, glucose absorption and postprandial hyperglycemia [248,249]. In fact, the antidiabetic activity of $F$. vesiculosus was even demonstrated in a human trial in which a single 
ingestion of $250 \mathrm{mg}$ of InSea ${ }^{2 \mathrm{TM}}$ (a commercial extract of F. vesiculosus and Ascophyllum nodosum, INNOVACTIV Inc., Rimouski, QC, Canada), $30 \mathrm{~min}$ prior to the consumption of $50 \mathrm{~g}$ of carbohydrates, caused a reduction of the insulin incremental area of the curve by $12.1 \%$ and an increase of the insulin sensitivity by $7.9 \%[250]$.<smiles>Oc1cc(O)c(Oc2cc(O)c(Oc3cc(O)c(O)c(O)c3)c(O)c2)c(O)c1</smiles><smiles>Oc1cc(O)cc(Oc2c(O)cc(O)cc2Oc2c(O)cc(O)cc2O)c1</smiles><smiles>Oc1cc(O)c(-c2c(O)cc(O)cc2O)c(O)c1</smiles>

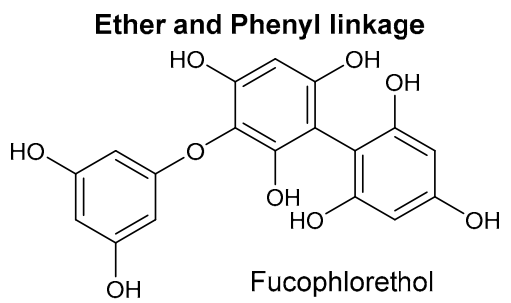<smiles>CCOc1cc(O)cc(O)c1Oc1c(O)cc(O)c(Oc2cc(O)cc(O)c2)c1O</smiles>

Dibenzodioxin linkage<smiles>Oc1cc(O)c(Oc2cc3c(c(O)c2O)Oc2cc(O)c(Oc4cc(O)c(O)c(O)c4)c(O)c2O3)c(O)c1</smiles>

Figure 4. Examples of phlorotannin structures grouped according to their type of linkage. Structures redrawn from [251,252].

Other potential biological properties of Fucus spp. phlorotannins include antitumor [253,254], antimicrobial [255,256], anti-hypertensive [257], anti-obesity [245] and photoprotective [258], although studies focusing these bioactivities are still incipient.

\section{Fucus spp. as a Functional Ingredient}

Although the term "functional foods" keeps earning more and more popularity worldwide, there is still no clear definition for it. Nevertheless, these are commonly accepted as foods (and food components) that provide specific health benefits beyond the basic nourishment. Generally, these foods are intended to be consumed as part of the normal diet and contain biologically active components which offer the potential of enhanced health or reduced risk of disease [259].

Since seaweeds have proven to possess promising health beneficial effects, they appear to be good candidates for application as functional ingredients in the design of novel functional foods. In fact, according to the SeafoodSource report, the new products containing this "new ingredient" launched on the European market between 2011 and 2015 increased by 147\%, making Europe the most innovative region globally after Asia Pacific [260]. In this field, the use of Fucus spp. and/or its extracts for development of food with improved nutritional qualities and functionalities have already taken some steps (Table 6). 
In this context, O'Sullivan et al. [22] used F. vesiculosus ethanol $60 \%$ extract at 0.25 and $0.5 \%$ $(w / w)$ to produce a novel dairy product. The authors observed that when incorporated at the highest concentration, the extract provided antioxidant functionality in milk either before or after in vitro digestion. The ability was however not observed in cellular models, suggesting that fortification with $F$. vesiculosus could improve certain milk qualities and shelf-life characteristics, but did not provide significant biological activity. Furthermore, milk enriched with F. vesiculosus presented a green/yellowish color and fishy taste that was not generally well accepted in the sensorial evaluation. Further studies conducted by this research group on fortified yogurts with the same $F$. vesiculosus ethanolic extract $(0.5 \% w / w)$ also revealed an increment of the antioxidant activity before and after in vitro digestion, without affecting product's acidity, microbiology or whey separation parameters. However, once again, the biological activity on cellular models was absent and sensorial analysis had low acceptability [21].

Table 6. Effect of functional foods enriched with Fucus components.

\begin{tabular}{|c|c|c|c|c|}
\hline Functional Food & Functional Ingredient & Quantities & Results & Ref. \\
\hline Milk & $\begin{array}{c}\text { F. vesiculosus } 60 \% \mathrm{EtOH} \\
\text { extract }\end{array}$ & $0.25 \%$ and $0.5 \%$ & $\begin{array}{l}\text { - Extract was stable in milk and provided } \\
\text { antioxidant activity before and after in vitro } \\
\text { digestion, but not in cells } \\
\text { - Improvement of certain milk quality and } \\
\text { shelf-life characteristics } \\
\text { - Milk sensorial attributes were worsened }\end{array}$ & [22] \\
\hline Yogurt & $\begin{array}{l}\text { F. vesiculosus } 40 \% \\
\text { EtOH extract }\end{array}$ & $0.25 \%$ and $0.5 \%$ & $\begin{array}{l}\text { - No influence on product's acidity, } \\
\text { microbiology or whey separation parameters } \\
\text { - Increment of the antioxidant activity before } \\
\text { and after in vitro digestion } \\
\text { - Improvement of certain yogurt quality and } \\
\text { shelf-life characteristics } \\
\text { - Yogurt sensorial attributes were worsened }\end{array}$ & [21] \\
\hline Fish cakes & $\begin{array}{l}\text { F. vesiculosus extracts: } \\
100 \% \mathrm{H}_{2} \mathrm{O}, 80 \% \mathrm{EtOH}\end{array}$ & $\begin{array}{l}3.7 \text { and } 3.8 \mathrm{~g} / 100 \mathrm{~g}\left(\mathrm{H}_{2} \mathrm{O} \text { and }\right. \\
\text { EtOH extract, respectively) }\end{array}$ & $\begin{array}{l}\text { - No off-flavors and lower rancid odor and } \\
\text { flavor } \\
\text {-None of the extracts had influence on lipid } \\
\text { oxidation nor quality of the products }\end{array}$ & [261] \\
\hline Cod muscle & $\begin{array}{l}\text { EtOAc fraction of } \\
\text { F. vesiculosus } 80 \% \\
\text { EtOH extract }\end{array}$ & $300 \mathrm{mg}$ PGE / kg & $\begin{array}{l}\text { - Application of seaweed extract acted against } \\
\text { lipid oxidation in fish muscle foods. }\end{array}$ & [262] \\
\hline Cod mince & $\begin{array}{l}\text { F. vesiculosus } 80 \% \text { EtOH } \\
\text { extract and further fractions } \\
\text { (EtOAc + Sephadex LH-20) }\end{array}$ & $300 \mathrm{mg} / \mathrm{kg}$ & $\begin{array}{l}\text { - Phlorotannin-rich fractions had higher } \\
\text { inhibitory impact on lipid peroxidation than } \\
\text { crude } 80 \% \text { ethanol extracts } \\
\text { - Some phlorotannin-rich sub-fractions had an } \\
\text { effect comparable to that of } 100 \mathrm{mg} / \mathrm{kg} \text { propyl } \\
\text { gallate. }\end{array}$ & [263] \\
\hline $\begin{array}{l}\text { Cod protein } \\
\text { hydrolysates }\end{array}$ & $\begin{array}{l}\text { F. vesiculosus: EtOAc fraction } \\
\text { from an } 80 \% \text { EtOH extract }\end{array}$ & $62.0 \mathrm{~g}$ PGE $/ 100 \mathrm{~g}$ & $\begin{array}{l}\text { - Decreased lipid hydroperoxide and TBARS } \\
\text { values during protein hydrolyzation } \\
\text { - Increased antioxidant activity of the final } \\
\text { protein hydrolysates }\end{array}$ & [264] \\
\hline $\begin{array}{l}\text { Cod bone mince } \\
\text { protein } \\
\text { hydrolysates }\end{array}$ & $\begin{array}{l}\text { F. vesiculosus: EtOAc fraction } \\
\text { from an } 80 \% \text { EtOH extract }\end{array}$ & $\begin{array}{l}0.16 \mathrm{~g} \mathrm{PGE} / \mathrm{L} \text { of } 3.7 \%(w / v) \operatorname{cod} \\
\text { bone mince }\end{array}$ & $\begin{array}{l}\text { - Prevented lipid oxidation during protein } \\
\text { hydrolysates freeze drying } \\
\text { - Slightly increased antioxidant activity of the } \\
\text { final protein hydrolysates } \\
\text { - Improved the bitter, soap, fish oil and } \\
\text { rancidity taste of the final protein hydrolysates }\end{array}$ & [265] \\
\hline $\begin{array}{l}\text { Minced horse } \\
\text { mackerel }\end{array}$ & $\begin{array}{l}\text { F. vesiculosus antioxidant } \\
\text { dietary fiber }\end{array}$ & $1 \%$ and $2 \%$ & $\begin{array}{l}\text { - Prevented lipid oxidation during } 5 \text { months of } \\
\text { storage at }-20^{\circ} \mathrm{C} \text {. } \\
\text { - Reduced total yield after thawing and cooking } \\
\text { after up to } 3 \text { months of frozen storage }\end{array}$ & [20] \\
\hline $\begin{array}{l}\text { Fish-oil-enriched } \\
\text { granola bars }\end{array}$ & $\begin{array}{l}\text { F. vesiculosus extracts: } 100 \% \\
\mathrm{H}_{2} \mathrm{O}, 70 \% \text { ACN, } 80 \% \text { EtOH }\end{array}$ & 0.5 and $1.0 \mathrm{~g} / 100 \mathrm{~g}$ & $\begin{array}{l}\text { - The highest antioxidant effect and lipid } \\
\text { stability improvement was observed for EtOH } \\
\text { and ACN extracts at } 0.5 \mathrm{~g} / 100 \mathrm{~g} \text {. } \\
\text { - } \mathrm{H}_{2} \mathrm{O} \text { extract only showed positive effects for } \\
\text { the concentration } 1.0 \mathrm{~g} / 100 \mathrm{~g}\end{array}$ & [266] \\
\hline $\begin{array}{l}\text { Fish-oil-enriched } \\
\text { milk and } \\
\text { mayonnaise }\end{array}$ & $\begin{array}{l}\text { F. vesiculosus: EtOAc fraction } \\
\text { from an } 80 \% \text { EtOH extract, } \\
\qquad 100 \% \mathrm{H}_{2} \mathrm{O}\end{array}$ & $1.0-2.0 \mathrm{~g} / 100 \mathrm{~g}$ & $\begin{array}{l}\text { - EtOAc fraction caused significant } \\
\text { improvement of milk's lipid stability in a } \\
\text { dose-dependent fashion, decreasing the } \\
\text { degradation of EPA and DHA and subsequent } \\
\text { secondary degradation products } \\
\text { - } \mathrm{H}_{2} \mathrm{O} \text { extract at } 2.0 \mathrm{~g} / 100 \text { g exerted higher } \\
\text { inhibitory effects on mayonnaise's peroxide } \\
\text { formation. Lower concentrations had } \\
\text { pro-oxidant effect }\end{array}$ & [19] \\
\hline
\end{tabular}


Table 6. Cont.

\begin{tabular}{|c|c|c|c|c|}
\hline Functional Food & Functional Ingredient & Quantities & Results & Ref. \\
\hline $\begin{array}{l}\text { Fish-oil-enriched } \\
\text { mayonnaise }\end{array}$ & $\begin{array}{l}\text { F. vesiculosus extracts: } 100 \% \\
\mathrm{H}_{2} \mathrm{O}, 70 \% \text { ACN, } 80 \% \text { EtOH }\end{array}$ & 1.5 and $2.0 \mathrm{~g} / \mathrm{kg}$ & $\begin{array}{l}\text { - The higher the concentration, the better the } \\
\text { inhibitory effect of EtOH and ACN extracts } \\
\text { against lipid oxidation. } \\
\text { - Water extracts caused pro-oxidant effects, } \\
\text { probably due to high contents of trace metals. }\end{array}$ & [267] \\
\hline Canola oil & F. vesiculosus $\mathrm{H}_{2} \mathrm{O}$ extracts & $500 \mathrm{ppm}$ & $\begin{array}{c}\text { - Peroxide, } p \text {-anisidine, total oxidation and } \\
\text { conjugated dienes values decreased } \\
\text { approximately 70\% comparing to the control } \\
\text { and } 40 \% \text { comparing to BHT } \\
\text { - TBARS values decreased approximately } 50 \% \\
\text { comparing to the control and } 30 \% \text { comparing } \\
\text { to BHT }\end{array}$ & [268] \\
\hline
\end{tabular}

Several authors also reported the use of $F$. vesiculosus extracts for development of novel fish and fish-derived food products. Indeed, the application of $F$. vesiculosus ethyl acetate extract to hemoglobin-fortified washed cod mince was found to effectively reduce the lipid and protein oxidation events in the food, suggesting that this seaweed extract could have great potential to be used as a natural antioxidant agent in fish muscle foods [262]. Similar studies further confirmed that the ethyl acetate fraction of $F$. vesiculosus extract not only could effectively prevent the hemoglobin-mediated lipid oxidation occurring during cod protein enzymatic hydrolysis as also significantly contributed for an enhancement of the fish protein hydrolysates antioxidant activity [265]. Additionally, this $F$. vesiculosus fraction was also shown to decrease the rancid, bitter, soap and fish oil tastes of cod bone mince-fish protein hydrolysates, thus contributing for their overall better tasting [264]. Nevertheless, due to the safety implications associated to the use of organic solvents in products for direct human consumption, the use of ethyl acetate extracts would be very limitative if considering their application as food ingredients.

In a recent study, the addition of $F$. vesiculosus aqueous or ethanol extracts to $\omega 3$ enriched fish cakes revealed that, although no significant differences were seen regarding to the cakes' lipid oxidation or quality, no off-flavors and even lower rancid odor and flavor was noticed when comparing to the control cakes [261]. On the other hand, F. vesiculosus ethanol extracts and subsequent phlorotannin-purified fractions have shown promising results in two cod model systems, namely hemoglobin-mediated lipid oxidation in washed cod muscle and cod protein isolates. In fact, the use of different oligomeric phlorotannin subfractions $(300 \mathrm{mg} / \mathrm{kg}$ ) were even capable of completely inhibiting initiation of lipid peroxidation in both cod model systems throughout the entire study period (eight days), thus exhibiting an effect comparable to that of $100 \mathrm{mg} / \mathrm{kg}$ of propyl gallate, i.e., a highly effective synthetic antioxidant in muscle foods [263]. Diaz-Rubio et al. [20] also demonstrated that the addition of $1 \%$ or $2 \%$ of $F$. vesiculosus antioxidant dietary fiber to minced horse mackerel contributes to the reduction of fish's lipid oxidation during its storage. However, even though the palatability of the $2 \%$ F. vesiculosus fiber-supplemented fish samples was not impaired, an alteration of the fish flavor was noticed in the sensorial analysis.

As an alternative to the direct application of Fucus extracts into the fish matrix, studies have been carried out to evaluate the possible preservative effects of Fucus spp. when added to the icing medium conventionally used for storage and preservation of fresh fish. In this field, the work of Rodrigues [269] revealed that, although the ice supplementation with F. spiralis ethanolic extracts presented high antioxidant activity and stability over 60 days, its capacity to delay or inhibit the lipid oxidation of sardine fillets was very low. On the other hand, the use of a F. spiralis-supplemented ice medium for storage of megrim over 14 days significantly inhibited the microbial activity of several microorganisms including aerobes, psychrotrophs, proteolytic bacteria and lipolytic bacteria, as well as the $\mathrm{pH}$ raise and lipid oxidation of the fish samples compared to the control [270]. The main difference between these two studies is that, the sardine fillets were placed on top of the supplemented ice, while the megrim 
fishes were covered with the supplemented ice. Therefore, upon ice thawing, F. spiralis extract was washed over megrim fishes but not on sardine fillets, which could explain these contradictory results.

F. vesiculosus extracts have also been found to be particularly useful for preventing lipid oxidation in fish-oil-enriched foods. For instance, Karadag et al. [266] reported that the introduction of F. vesiculosus ethanol and acetone extract at $0.5 \mathrm{~g} / 100 \mathrm{~g}$ exhibited the most efficient antioxidant effect and highest improvement of the bars lipid stability, while water extracts only exerted positive effects for the concentration $1.0 \mathrm{~g} / 100 \mathrm{~g}$. Previous studies revealed that the addition of $1.0-2.0 \mathrm{~g} / \mathrm{kg}$ of a phenolic and carotenoid-rich fraction from a $F$. vesiculosus $80 \%$ ethanol extract to fish-oil-enriched milk dose-dependently enhanced its lipid stability as well [19]. On the other hand, despite its lower content of phenolics and pigments, the addition of $2.0 \mathrm{~g} / \mathrm{kg}$ of a F. vesiculosus water extract to fish-oil-enriched mayonnaise exhibited the highest inhibitory effect against peroxide formation, possibly due to its higher metal chelating capacity and presence of other highly polar compounds than phenolic compounds [19]. In a similar study, the addition of $1.5-2.0 \mathrm{~g} / \mathrm{kg}$ of ethanol or acetone F. vesiculosus extracts to fish-oil-enriched mayonnaise was also shown to cause a dose-dependent reduction of lipid oxidation reactions and hydroperoxides formation, however, the addition of water extracts exerted an opposite effect, i.e., acted as a pro-oxidant. This result could be a consequence not only of the lower phenolic and carotenoid content compared to the ethanol and acetone extracts but also due to the much higher content in trace metals, namely $\mathrm{Fe}$, which could be stimulating the oxidative reactions [267]. Recently, aiming the substitution of the synthetic antioxidant 2,6-D-tert-butyl-4-methylphenol (BHT) conventionally used as a stabilizer in food products, Agregán et al. [268] developed a F. vesiculosus-fortified canola oil. According to the authors, after 16 days of accelerated storage conditions (at $60^{\circ} \mathrm{C}$ ), the canola oil fortified with $500 \mathrm{ppm}$ of $F$. vesiculosus extract exhibited a reduction of the peroxides formation of approximately $70 \%$ compared to the control, which was much lower than values observed for canola oil fortified with $50 \mathrm{ppm}$ of BHT (approximately $30 \%$ ). Therefore, according to these studies, it is possible to propose that Fucus spp. extracts with high phenolic and/or carotenoid contents could be used not only as natural antioxidants for food preservation but also to replace the use of synthetic compounds commonly used for those purposes.

\section{Concluding Remarks}

Fucus spp. are very valuable food sources with high nutritional value and low in calories due to their low content of lipids and poor bioavailable polysaccharides. Although the nutrient content of this genus is highly dependent of seasonal, environmental, genetic and other variations, it is generally very rich in dietary fiber, constituting an important source of fucoidan and alginic acid. Furthermore, the mineral content of Fucus spp. is also very rich, surpassing that of common terrestrial vegetables. Algae from this genus generally contain high amounts of $\mathrm{Na}$ and $\mathrm{K}$, although their ratio is low, which could be useful for the regulation of the $\mathrm{Na} / \mathrm{K}$ imbalance in Western countries. Moreover, these algae can accumulate high concentrations of iodine which is deficient in almost half of the European population and is very important for the thyroid function. Although these macroalgae are not the abundant in protein when compared to red or green seaweeds, their protein levels are still higher than those of some terrestrial plants commonly considered as high vegetable protein suppliers, containing all nine essential amino acids and being particularly rich in glutamic and aspartic acids. Likewise, despite the low lipid content, Fucus spp. lipid profile is highly abundant in PUFAs displaying very low $\omega 6 / \omega 3$ ratios contrary to what is currently observed in Western diets.

Fucus spp. algae are also a valuable source of bioactive compounds that could be explored for the development of natural agents with therapeutic applications. Among them, one can highlight the fucoidans and the phlorotannins, although there are others equally important such as vitamins and fucoxanthin. These compounds have drawn much attention during the recent years due to their numerous possible therapeutic properties. Common features among them are the good antioxidant effects through scavenging of ROS or enhancement of intracellular antioxidant defenses, good anti-carcinogenic effects through activation of apoptosis on cancerous cells and inhibition 
of metastasis and angiogenesis, and good anti-inflammatory effects through inhibition of several pro-inflammatory mediators. Other important biological activities have been demonstrated such as anti-obesity, anti-diabetes, anti-microbial or anti-photoaging activities, and, in the case of fucoidan, anti-coagulant/anti-thrombotic activities as well. Therefore, it can be suggested that not only Fucus spp. nutrition value could valuably contribute for the improvement of the dietary quality of Western countries but also the presence of compounds with such powerful and versatile bioactivities grant them great potential to be exploited as renewable feedstocks for extraction of natural active ingredients for development of new added-value products. Particularly in food industry, Fucus spp. has already demonstrated to be particularly useful for improvement of foods quality and shelf-lives, as well as for the development of novel functional foods. Nevertheless, numerous other applications could be given to this genus, namely in the field of nutraceutical, cosmeceutical and pharmaceutical products development. With this manuscript, we hope to raise the awareness for the multiple applications of Fucus-derived products, as well as to contribute to boost their commercial interest.

Author Contributions: Conceptualization, M.D.C. and S.M.C.; Writing-Original Draft Preparation, M.D.C.; Writing-Review \& Editing, S.M.C. and A.M.S.S.; Supervision, S.M.C.

Funding: This work was funded by the R\&D Co-promotion project POCI-01-0247-FEDER-003419, SHARP-Seaweed for Healthier Traditional Products, co-financed by the European Regional Development Fund through the Competitive and Internationalization Thematic Operational Program under the Portugal 2020 Program; Science and Technology Foundation/Ministry of Education and Science (FCT/MEC) funded the Organic Chemistry, Natural Products and Food Stuffs Research Unit (QOPNA) research Unit (FCT UID/QUI/00062/2013), through national funds and, where applicable, co-financed by the European Regional Development Fund (FEDER), within the Portugal 2020; Project AgroForWealth (CENTRO-01-0145-FEDER-000001), funded by Centro2020, through FEDER and PT2020, financed the research contract of Susana M. Cardoso; Science and Technology Foundation financed Marcelo D. Catarino (fellowship PD/BD/114577/2016).

Conflicts of Interest: The authors declare no conflict of interest.

\section{References}

1. Kılınç, B.; Cirik, S.; Turan, G. Seaweeds for Food and Industrial Applications. 2013, pp. 735-748. Available online: http://cdn.intechopen.com/pdfs/41694/InTech-Seaweeds_for_food_and_industrial_applications. pdf (accessed on 25 July 2018).

2. Bocanegra, A.; Bastida, S.; Benedi, J.; Rodenas, S.; Sanchez-Muniz, F.J. Characteristics and nutritional and cardiovascular-health properties of seaweeds. J. Med. Food 2013, 12, 236-258. [CrossRef] [PubMed]

3. Cardoso, S.; Carvalho, L.; Silva, P.; Rodrigues, M.; Pereira, O.; Pereira, L. Bioproducts from Seaweeds: A Review with Special Focus on the Iberian Peninsula. Curr. Org. Chem. 2014, 18, 896-917. [CrossRef]

4. Cardoso, S.; Pereira, O.; Seca, A.; Pinto, D.; Silva, A. Seaweeds as preventive agents for cardiovascular diseases: From nutrients to functional foods. Mar. Drugs 2015, 13, 6838-6865. [CrossRef] [PubMed]

5. Future Foods: What Will We Be Eating in 20 Years' Time? BBC News Mag. 2012. Available online: http: //www.bbc.com/news/magazine-18813075 (accessed on 25 July 2018).

6. AlgaeBase, World-Wide Electronic Publication. Available online: https://ci.nii.ac.jp/naid/20001423979/ (accessed on 23 July 2018).

7. Kucera, H.; Saunders, G.W. Assigning morphological variants of Fucus (Fucales, Phaeophyceae) in Canadian waters to recognized species using DNA barcoding. Botany 2008, 86, 1065-1079. [CrossRef]

8. Torn, K.; Krause-Jensen, D.; Martin, G. Present and past depth distribution of bladderwrack (Fucus vesiculosus) in the Baltic Sea. Aquat. Bot. 2006, 84, 53-62. [CrossRef]

9. Ar Gall, E.; Le Duff, M.; Sauriau, P.G.; De Casamajor, M.N.; Gevaert, F.; Poisson, E.; Hacquebart, P.; Joncourt, Y.; Barillé, A.L.; Buchet, R.; et al. Implementation of a new index to assess intertidal seaweed communities as bioindicators for the European Water Framework Directory. Ecol. Indic. 2016, 60, 162-173. [CrossRef]

10. Bordeyne, F.; Davoult, D.; Migné, A.; Bertaud du Chazaud, E.; Leroux, C.; Riera, P. Trophic structure of two intertidal Fucus spp. communities along a vertical gradient: Similarity and seasonal stability evidenced with $\delta 13 \mathrm{C}$ and $815 \mathrm{~N}$. J. Sea Res. 2017, 120, 50-59. [CrossRef]

11. Pereira, L. Edible Seaweeds of the World, 1st ed.; CRC Press: Boca Raton, FL, USA, 2016. 
12. Patarra, R.F.; Paiva, L.; Neto, A.I.; Lima, E.; Baptista, J. Nutritional value of selected macroalgae. J. Appl. Phycol. 2011, 23, 205-208. [CrossRef]

13. Küpper, F.C.; Feiters, M.C.; Olofsson, B.; Kaiho, T.; Yanagida, S.; Zimmermann, M.B.; Carpenter, L.J.; Luther, G.W.; Lu, Z.; Jonsson, M.; et al. Commemorating two centuries of iodine research: An interdisciplinary overview of current research. Angew. Chem. Int. Ed. 2011, 50, 11598-11620. [CrossRef] [PubMed]

14. Pereira, L. A review of the nutrient composition of selected edible seaweeds. In Seaweed: Ecology, Nutrient Composition and Medicinal Uses; Pomin, V.H., Ed.; Nova Science Publishers, Inc.: Hauppauge, NY, USA, 2011; pp. $15-47$.

15. Ale, M.T.; Mikkelsen, J.D.; Meyer, A.S. Important determinants for fucoidan bioactivity: A critical review of structure-function relations and extraction methods for fucose-containing sulfated polysaccharides from brown seaweeds. Mar. Drugs 2011, 9, 2106-2130. [CrossRef] [PubMed]

16. Laekeman, G. Assessment Report on Fucus vesiculosus L., Thallus. Available online: http:/ /203.187.160.132: 9011/www.ema.europa.eu/c3pr90ntc0td/docs/en_GB/document_library/Herbal_-_HMPC_assessment_ report/2015/07/WC500190398.pdf (accessed on 25 July 2018).

17. Min, S.-K.; Han, S.-M.; Kim, H.-T.; Kwon, O.-C.; Lee, S.; Kim, J.-K. Algal fucoidan, unlike heparin, has thrombolytic activity in a murine arterial thrombosis model. Blood Coagul. Fibrinolysis 2012, 23, 359-366. [CrossRef] [PubMed]

18. Díaz-Rubio, M.E.; Pérez-Jiménez, J.; Saura-Calixto, F.; Diaz-Rubio, M.E.; Perez-Jimenez, J.; Saura-Calixto, F. Dietary fiber and antioxidant capacity in Fucus vesiculosus products. Int. J. Food Sci. Nutr. 2009, 60, $23-34$. [CrossRef] [PubMed]

19. Hermund, D.B.; Yeşiltaş, B.; Honold, P.; Jónsdóttir, R.; Kristinsson, H.G.; Jacobsen, C. Characterisation and antioxidant evaluation of Icelandic F. vesiculosus extracts in vitro and in fish-oil-enriched milk and mayonnaise. J. Funct. Foods 2015, 19, 828-841. [CrossRef]

20. Diaz-Rubio, M.E.; Serrano, J.; Borderias, J.; Saura-Calixto, F. Technological Effect and Nutritional Value of Dietary Antioxidant Fucus Fiber Added to Fish Mince. J. Aquat. Food Prod. Technol. 2011, 20, $295-307$. [CrossRef]

21. O'Sullivan, A.M.; O'Grady, M.N.; O'Callaghan, Y.C.; Smyth, T.J.; O'Brien, N.M.; Kerry, J.P. Seaweed extracts as potential functional ingredients in yogurt. Innov. Food Sci. Emerg. Technol. 2015, 37, 293-299. [CrossRef]

22. O'Sullivan, A.M.; O'Callaghan, Y.C.; O'Grady, M.N.; Waldron, D.S.; Smyth, T.J.; O’Brien, N.M.; Kerry, J.P. An examination of the potential of seaweed extracts as functional ingredients in milk. Int. J. Dairy Technol. 2014, 67, 182-193. [CrossRef]

23. Wen, X.; Peng, C.; Zhou, H.; Lin, Z.; Lin, G.; Chen, S.; Li, P. Nutritional Composition and Assessment of Gracilaria lemaneiformis Bory. J. Integr. Plant Biol. 2006, 48, 1047-1053. [CrossRef]

24. Paiva, L.; Lima, E.; Patarra, R.F.; Neto, A.I.; Baptista, J. Edible Azorean macroalgae as source of rich nutrients with impact on human health. Food Chem. 2014, 164, 128-135. [CrossRef] [PubMed]

25. Kostas, E.T.; White, D.A.; Du, C.; Cook, D.J. Selection of yeast strains for bioethanol production from UK seaweeds. J. Appl. Phycol. 2016, 28, 1427-1441. [CrossRef] [PubMed]

26. Marsham, S.; Scott, G.W.; Tobin, M.L. Comparison of nutritive chemistry of a range of temperate seaweeds. Food Chem. 2007, 100, 1331-1336. [CrossRef]

27. Sharma, S.H.S.; Lyons, G.; McRoberts, C.; McCall, D.; Carmichael, E.; Andrews, F.; Swan, R.; McCormack, R.; Mellon, R. Biostimulant activity of brown seaweed species from Strangford Lough: Compositional analyses of polysaccharides and bioassay of extracts using mung bean (Vigno mungo L.) and pak choi (Brassica rapa chinensis L.). J. Appl. Phycol. 2012, 24, 1081-1091. [CrossRef]

28. Kim, M.K.; Dubacq, J.P.; Thomas, J.C.; Giraud, G. Seasonal variations of triacylglycerols and fatty acids in Fucus serratus. Phytochemistry 1996, 43, 49-55. [CrossRef]

29. Tedesco, S.; Benyounis, K.Y.; Olabi, A.G. Mechanical pretreatment effects on macroalgae-derived biogas production in co-digestion with sludge in Ireland. Energy 2013, 61, 27-33. [CrossRef]

30. López Barreiro, D.; Beck, M.; Hornung, U.; Ronsse, F.; Kruse, A.; Prins, W. Suitability of hydrothermal liquefaction as a conversion route to produce biofuels from macroalgae. Algal Res. 2015, 11, $234-241$. [CrossRef]

31. Madden, M.; Mitra, M.; Ruby, D.; Schwarz, J. Seasonality of selected nutritional constituents of edible delmarva seaweeds. J. Phycol. 2012, 48, 1289-1298. [CrossRef] [PubMed] 
32. Herbreteau, F.; Coiffard, L.J.M.; Derrien, A.; De Roeck-Holtzhauer, Y. The fatty acid composition of five species of macroalgae. Bot. Mar. 1997, 40, 25-28. [CrossRef]

33. Jiao, G.; Yu, G.; Wang, W.; Zhao, X.; Zhang, J.; Ewart, S.H. Properties of polysaccharides in several seaweeds from Atlantic Canada and their potential anti-influenza viral activities. J. Ocean Univ. China 2012, 11, $205-212$. [CrossRef]

34. Ruperez, P.; Saura-Calixto, F. Dietary fibre and physicochemical properties of edible Spanish seaweeds. Eur. Food Res. Technol. 2001, 212, 349-354. [CrossRef]

35. Bogolitsyn, K.G.; Kaplitsin, P.A.; Pochtovalova, A.S. Amino-acid composition of artic brown algae. Chem. Nat. Compd. 2014, 49, 954-957. [CrossRef]

36. Rioux, L.E.; Turgeon, S.L.; Beaulieu, M. Characterization of polysaccharides extracted from brown seaweeds. Carbohydr. Polym. 2007, 69, 530-537. [CrossRef]

37. Patarra, R.F.; Leite, J.; Pereira, R.; Baptista, J.; Neto, A.I. Fatty acid composition of selected macrophytes. Nat. Prod. Res. 2013, 27, 665-669. [CrossRef] [PubMed]

38. Khotimchenko, S.V.; Vaskovsky, V.E.; Titlyanova, T.V. Fatty acids of marine algae from the pacific coast of North California. Bot. Mar. 2002, 45, 17-22. [CrossRef]

39. Holdt, S.L.; Kraan, S. Bioactive compounds in seaweed: Functional food applications and legislation. J. Appl. Phycol. 2011, 23, 543-597. [CrossRef]

40. Dawczynski, C.; Schubert, R.; Jahreis, G. Amino acids, fatty acids, and dietary fibre in edible seaweed products. Food Chem. 2007, 103, 891-899. [CrossRef]

41. Brown, E.M.; Allsopp, P.J.; Magee, P.J.; Gill, C.I.; Nitecki, S.; Strain, C.R.; Mcsorley, E.M. Seaweed and human health. Nutr. Rev. 2014, 72, 205-216. [CrossRef] [PubMed]

42. Obluchinskaya, E.D.; Voskoboinikov, G.M.; Galynkin, V.A. Contents of alginic acid and fucoidan in Fucus algae of the Barents Sea. Appl. Biochem. Microbiol. 2002, 38, 186-188. [CrossRef]

43. Imbs, T.I.; Skriptsova, A.V.; Zvyagintseva, T.N. Antioxidant activity of fucose-containing sulfated polysaccharides obtained from Fucus evanescens by different extraction methods. J. Appl. Phycol. 2015, 27, 545-553. [CrossRef]

44. Malyarenko, O.S.; Usoltseva, R.V.; Shevchenko, N.M.; Isakov, V.V.; Zvyagintseva, T.N.; Ermakova, S.P. In vitro anticancer activity of the laminarans from Far Eastern brown seaweeds and their sulfated derivatives. J. Appl. Phycol. 2017, 29, 543-553. [CrossRef]

45. Skriptsova, A.V.; Shevchenko, N.M.; Tarbeeva, D.V.; Zvyagintseva, T.N. Comparative study of polysaccharides from reproductive and sterile tissues of five brown seaweeds. Mar. Biotechnol. 2012, 14, 304-311. [CrossRef] [PubMed]

46. Zvyagintseva, T.N.; Shevchenko, N.M.; Chizhov, A.O.; Krupnova, T.N.; Sundukova, E.V.; Isakov, V.V. Water-soluble polysaccharides of some far-eastern brown seaweeds. Distribution, structure, and their dependence on the developmental conditions. J. Exp. Mar. Bio. Ecol. 2003, 294, 1-13. [CrossRef]

47. Zvyagintseva, T.N.; Shevchenko, N.M.; Nazarenko, E.L.; Gorbach, V.I.; Urvantseva, A.M.; Kiseleva, M.I.; Isakov, V.V. Water-soluble polysaccharides of some brown algae of the Russian Far-East. Structure and biological action of low-molecular mass polyuronans. J. Exp. Mar. Bio. Ecol. 2005, 320, 123-131. [CrossRef]

48. Bilan, M.I.; Grachev, A.A.; Ustuzhanina, N.E.; Shashkov, A.S.; Nifantiev, N.E.; Usov, A.I. Structure of a fucoidan from the brown seaweed Fucus evanescens C. Ag. Carbohydr. Res. 2002, 337, 719-730. [CrossRef]

49. Hmelkov, A.B.; Zvyagintseva, T.N.; Shevchenko, N.M.; Rasin, A.B.; Ermakova, S.P. Ultrasound-assisted extraction of polysaccharides from brown alga Fucus evanescens. Structure and biological activity of the new fucoidan fractions. J. Appl. Phycol. 2018, 30, 2039-2046. [CrossRef]

50. Black, W.A.P. Seasonal variation in chemical composition of some of the littoral seaweeds common to scotland. Part II. Fucus serratus, Fucus vesiculosus, Fucus spiralis and Pelvetia canaliculata. J. Soc. Chem. Ind. 1949, 68, 183-189. [CrossRef]

51. Chapman, V.J.; Chapman, D.J. Minor Uses of Algae and Their Products, 3rd ed.; Chapman and Hall Ltd.: New York, NY, USA, 1980.

52. Obluchinskaya, E.D. Comparative chemical composition of the Barents Sea brown algae. Appl. Biochem. Microbiol. 2008, 44, 305-309. [CrossRef]

53. Radwan, A.; Davies, G.; Fataftah, A.; Ghabbour, E.A.; Jansen, S.A.; Willey, R.J. Isolation of humic acid from the brown algae Ascophyllum nodosum, Fucus vesiculosus, Laminaria saccharina and the marine angiosperm Zostera marina. J. Appl. Phycol. 1996, 8, 553-562. [CrossRef] 
54. García-Ríos, V.; Ríos-Leal, E.; Robledo, D.; Freile-Pelegrin, Y. Polysaccharides composition from tropical brown seaweeds. Phycol. Res. 2012, 60, 305-315. [CrossRef]

55. Black, W.A.P.; Dewar, E.T.; Woodward, F.N. Manufacture of algal chemicals. III. Laboratory-scale isolation of laminarin from brown marine algae. J. Appl. Chem. 1951, 1, 505-517. [CrossRef]

56. Bilan, M.I.; Grachev, A.A.; Shashkov, A.S.; Nifantiev, N.E.; Usov, A.I. Structure of a fucoidan from the brown seaweed Fucus serratus L. Carbohydr. Res. 2006, 341, 238-245. [CrossRef] [PubMed]

57. Bilan, M.I.; Grachev, A.A.; Ustuzhanina, N.E.; Shashkov, A.S.; Nifantiev, N.E.; Usov, A.I. A highly regular fraction of a fucoidan from the brown seaweed Fucus distichus L. Carbohydr. Res. 2004, 339, 511-517. [CrossRef] [PubMed]

58. Flórez-Fernández, N.; Torres, M.D.; González-Muñoz, M.J.; Domínguez, H. Potential of intensification techniques for the extraction and depolymerization of fucoidan. Algal Res. 2018, 30, 128-148. [CrossRef]

59. McHugh, D.J. A Guide to the Seaweed Industry, 1st ed.; FAO: Rome, Italy, 2003.

60. Paolucci, M.; Fabbrocini, A.; Volpe, M.G.; Varricchio, E.; Coccia, E. Development of biopolymers as binders for feed for farmed aquatic organisms. In Aquaculture; Muchlisin, Z.A., Ed.; InTech: Rijeka, Croatia, 2012; pp. 3-34.

61. Deniaud-Bouët, E.; Kervarec, N.; Michel, G.; Tonon, T.; Kloareg, B.; Hervé, C. Chemical and enzymatic fractionation of cell walls from Fucales: Insights into the structure of the extracellular matrix of brown algae. Ann. Bot. 2014, 114, 1203-1216. [CrossRef] [PubMed]

62. Pereira, L.; Ribeiro-Claro, P.J.A. Analysis by vibrational spectroscopy of seaweed with potential use in food, pharmaceutical and cosmetic industries. In Marine Algae: Biodiversity, Taxonomy, Environmental Assessment, and Biotechnology; Pereira, L., Neto, J.M., Eds.; CRC Press: Boca Raton, FL, USA, 2014; pp. 228-250.

63. Lee, K.Y.; Mooney, D.J. Alginate: Properties and biomedical applications. Prog. Polym. Sci. 2013, 37, $106-126$. [CrossRef] [PubMed]

64. Ikegami, S.; Umegakl, K.; Kawashima, Y.; Ichikawa, T. Viscous indigestible polysaccharides reduce accumulation of pentachlorobenzene in rats. Nutr. Pharmacol. Toxicol. 2018, 124, 754-760. [CrossRef] [PubMed]

65. Idota, Y.; Harada, H.; Tomono, T.; Morimoto, K.; Kobayashi, S.; Kakinuma, C.; Miyajima, C.; Kasahara, F.; Ogihara, T. Alginate enhances excretion and reduces absorption of strontium and cesium in rats. Biol. Pharm. Bull. 2013, 36, 485-491. [CrossRef] [PubMed]

66. Leiman, D.A.; Riff, B.P.; Morgan, S.; Metz, D.C.; Falk, G.W.; French, B.; Umscheid, C.A.; Lewis, J.D. Alginate therapy is effective treatment for GERD symptoms: A systematic review and meta-analysis. Dis. Esophagus 2017, 30, 1-9. [CrossRef] [PubMed]

67. Georg Jensen, M.; Knudsen, J.C.; Viereck, N.; Kristensen, M.; Astrup, A. Functionality of alginate based supplements for application in human appetite regulation. Food Chem. 2012, 132, 823-829. [CrossRef]

68. Jensen, M.G.; Kristensen, M.; Belza, A.; Knudsen, J.C.; Astrup, A. Acute effect of alginate-based preload on satiety feelings, energy intake, and gastric emptying rate in healthy subjects. Obesity 2012, 20, 1851-1858. [CrossRef] [PubMed]

69. Torsdottir, I.; Alpsten, M.; Holm, G.; Sandberg, A.S.; Tölli, J. A small dose of soluble alginate-fiber affects postprandial glycemia and gastric emptying in humans with diabetes. J. Nutr. 1991, 121, 795-799. [CrossRef] [PubMed]

70. Wolf, B.W.; Lai, C.S.; Kipnes, M.S.; Ataya, D.G.; Wheeler, K.B.; Zinker, B.A.; Garleb, K.A.; Firkins, J.L. Glycemic and insulinemic responses of nondiabetic healthy adult subjects to an experimental acid-induced viscosity complex incorporated into a glucose beverage. Nutrition 2002, 18, 621-626. [CrossRef]

71. Williams, J.A.; Lai, C.S.; Corwin, H.; Ma, Y.; Maki, K.C.; Garleb, K.A.; Wolf, B.W. Inclusion of guar gum and alginate into a crispy bar improves postprandial glycemia in humans. J. Nutr. 2004, 134, 886-889. [CrossRef] [PubMed]

72. Paxman, J.R.; Richardson, J.C.; Dettmar, P.W.; Corfe, B.M. Alginate reduces the increased uptake of cholesterol and glucose in overweight male subjects: A. pilot study. Nutr. Res. 2008, 28, 501-505. [CrossRef] [PubMed]

73. Sandberg, A.S.; Andersson, H.; Bosœus, I.; Carlsson, N.G.; Hasselblad, K.; Härröd, M. Alginate, small bowel sterol excretion, and absorption of nutrients in ileostomy subjects. Am. J. Clin. Nutr. 1994, 60, 751-756. [CrossRef] [PubMed]

74. Draget, K.I.; Moe, S.T.; Skjak-Bræk, G.; Smidsrød, O. Alginates. In Food Polysaccharides and Their Applications; Stephen, A.M., Phillips, G.O., Williams, P.A., Eds.; CRC Press: Boca Raton, FL, USA, 2006; pp. 289-334. 
75. Peteiro, C. Alginate production from marine macroalgae, with emphasis on kelp farming. In Alginates and Their Biomedical Applications; Rehm, B.H.A., Moradali, F., Eds.; Springer: Berlin, Germany, 2018; pp. $27-66$.

76. Truus, K.; Vaher, M.; Taure, I. Algal biomass from Fucus vesiculosus (Phaeophyta): Investigation of the mineral and alginate components. Proc. Estonian Acad. Sci. Chem. 2001, 50, 95-103.

77. Li, B.; Lu, F.; Wei, X.; Zhao, R. Fucoidan: Structure and bioactivity. Molecules 2008, 13, 1671-1695. [CrossRef] [PubMed]

78. Gupta, S.; Abu-Ghannam, N. Bioactive potential and possible health effects of edible brown seaweeds. Trends Food Sci. Technol. 2011, 22, 315-326. [CrossRef]

79. Chollet, L.; Saboural, P.; Chauvierre, C.; Villemin, J.N.; Letourneur, D.; Chaubet, F.; Laurienzo, P. Fucoidans in nanomedicine. Mar. Drugs 2016, 14, 145. [CrossRef] [PubMed]

80. Rodriguez-Jasso, R.; Mussatto, S.; Pastrana, L.; Aguilar, C.; Teixeira, J. Chemical composition and antioxidant activity of sulphated polysaccharides extracted from Fucus vesiculosus using different hydrothermal processes. Chem. Pap. 2014, 68, 203-209. [CrossRef]

81. Rocha De Souza, M.C.; Marques, C.T.; Guerra Dore, C.M.; Ferreira Da Silva, F.R.; Oliveira Rocha, H.A.; Leite, E.L. Antioxidant activities of sulfated polysaccharides from brown and red seaweeds. J. Appl. Phycol. 2007, 19, 153-160. [CrossRef] [PubMed]

82. Veena, C.K.; Josephine, A.; Preetha, S.P.; Varalakshmi, P. Beneficial role of sulfated polysaccharides from edible seaweed Fucus vesiculosus in experimental hyperoxaluria. Food Chem. 2007, 100, 1552-1559. [CrossRef]

83. Park, H.Y.; Han, M.H.; Park, C.; Jin, C.Y.; Kim, G.Y.; Choi, I.W.; Kim, N.D.; Nam, T.J.; Kwon, T.K.; Choi, Y.H. Anti-inflammatory effects of fucoidan through inhibition of NF-kB, MAPK and Akt activation in lipopolysaccharide-induced BV2 microglia cells. Food Chem. Toxicol. 2011, 49, 1745-1752. [CrossRef] [PubMed]

84. Kuznetsova, T.A. Fucoidan extracted from Fucus evanescens brown algae corrects immunity and hemostasis disorders in experimental endotoxemia. Bull. Exp. Biol. Med. 2009, 147, 66-69. [CrossRef] [PubMed]

85. Matsumoto, S.; Nagaoka, M.; Hara, T.; Kimura-Takagi, I.; Mistuyama, K.; Ueyama, S. Fucoidan derived from Cladosiphon okamuranus Tokida ameliorates murine chronic colitis through the down-regulation of interleukin-6 production on colonic epithelial cells. Clin. Exp. Immunol. 2004, 136, 432-439. [CrossRef] [PubMed]

86. Choi, J.; Raghavendran, H.R.B.; Sung, N.Y.; Kim, J.H.; Chun, B.S.; Ahn, D.H.; Choi, H.S.; Kang, K.W.; Lee, J.W. Effect of fucoidan on aspirin-induced stomach ulceration in rats. Chem. Biol. Interact. 2010, 183, 249-254. [CrossRef] [PubMed]

87. Lim, J.D.; Lee, S.R.; Kim, T.; Jang, S.A.; Kang, S.C.; Koo, H.J.; Sohn, E.; Bak, J.P.; Namkoong, S.; Kim, H.K.; et al. Fucoidan from Fucus vesiculosus protects against alcohol-induced liver damage by modulating inflammatory mediators in mice and Hepg2 cells. Mar. Drugs 2015, 13, 1051-1067. [CrossRef] [PubMed]

88. Myers, S.P.; Mulder, A.M.; Baker, D.G.; Robinson, S.R.; Rolfe, M.I.; Brooks, L.; Fitton, J.H. Effects of fucoidan from Fucus vesiculosus in reducing symptoms of osteoarthritis: A randomized placebo-controlled trial. Biol. Targets Ther. 2016, 10, 81-88.

89. Myers, S.P.; Wohlmuth, H.; Connor, J.O.; Rolfe, M.I.; Cheras, P.A.; Fitton, J.H. A combined phase I and II open label study on the effects of a seaweed extract nutrient complex on osteoarthritis. Biologics 2010, 4, 33-44. [CrossRef] [PubMed]

90. Kim, K.T.; Rioux, L.E.; Turgeon, S.L. $\alpha$-amylase and $\alpha$-glucosidase inhibition is differentially modulated by fucoidan obtained from Fucus vesiculosus and Ascophyllum nodosum. Phytochemistry 2014, 98, 27-33. [CrossRef] [PubMed]

91. Shan, X.; Liu, X.; Hao, J.; Cai, C.; Fan, F.; Dun, Y.; Zhao, X.; Liu, X.; Li, C.; Yu, G. In vitro and in vivo hypoglycemic effects of brown algal fucoidans. Int. J. Biol. Macromol. 2016, 82, 249-255. [CrossRef] [PubMed]

92. Kim, K.J.; Lee, O.H.; Lee, H.C.; Kim, Y.C.; Lee, B.Y. Effect of fucoidan on expression of diabetes mellitus related genes in mouse adipocytes. Food Sci. Biotechnol. 2007, 16, 212-217.

93. Jiang, X.; Yu, J.; Ma, Z.; Zhang, H.; Xie, F. Effects of fucoidan on insulin stimulation and pancreatic protection via the cAMP signaling pathway in vivo and in vitro. Mol. Med. Rep. 2015, 12, 4501-4507. [CrossRef] [PubMed]

94. Drozd, N.N.; Shevchenko, N.M.; Ermakova, S.P.; Lapikova, E.S.; Makarov, V.A.; Zvyagintseva, T.N. Effects of the structural characteristics of fucoidans from brown seaweeds on anticoagulant activity and the electrophoretic mobility of complexes with protamine sulfate. Pharm. Chem. J. 2011, 45, 56-61. [CrossRef] 
95. Lapikova, E.S.; Drozd, N.N.; Tolstenkov, A.S.; Makarov, V.A.; Zvyagintseva, T.N.; Shevchenko, N.M.; Bakunina, I.U.; Besednova, N.N.; Kuznetsova, T.A. Inhibition of thrombin and factor Xa by Fucus evanescens fucoidan and its modified analogs. Bull. Exp. Biol. Med. 2008, 146, 328-333. [CrossRef] [PubMed]

96. Cumashi, A.; Ushakova, N.A.; Preobrazhenskaya, M.E.; D'Incecco, A.; Piccoli, A.; Totani, L.; Tinari, N.; Morozevich, G.E.; Berman, A.E.; Bilan, M.I.; et al. A comparative study of the anti-inflammatory, anticoagulant, antiangiogenic, and antiadhesive activities of nine different fucoidans from brown seaweeds. Glycobiology 2007, 17, 541-552. [CrossRef] [PubMed]

97. Kuznetsova, T.A.; Besednova, N.N.; Mamaev, A.N.; Momot, A.P.; Shevchenko, N.M.; Zvyagintseva, T.N. Anticoagulant activity of fucoidan from brown algae Fucus evanescens of the Okhotsk Sea. Bull. Exp. Biol. Med. 2003, 136, 471-473. [CrossRef] [PubMed]

98. Ale, M.T.; Maruyama, H.; Tamauchi, H.; Mikkelsen, J.D.; Meyer, A.S. Fucose-containing sulfated polysaccharides from brown seaweeds inhibit proliferation of melanoma cells and induce apoptosis by activation of caspase-3 in vitro. Mar. Drugs 2011, 9, 2605-2621. [CrossRef] [PubMed]

99. Aisa, Y.; Miyakawa, Y.; Nakazato, T.; Shibata, H.; Saito, K.; Ikeda, Y.; Kizaki, M. Fucoidan induces apoptosis of human HS-Sultan cells accompanied by activation of caspase-3 and down-regulation of ERK pathways. Am. J. Hematol. 2005, 78, 7-14. [CrossRef] [PubMed]

100. Arafuka, S.; Koshiba, N.; Takahashi, D.; Toshima, K. Systematic synthesis of sulfated oligofucosides and their effect on breast cancer MCF-7 cells. Org. Biomol. Chem. 2014, 50, 9785-9982. [CrossRef] [PubMed]

101. Kasai, A.; Arafuka, S.; Koshiba, N.; Takahashi, D.; Toshima, K. Systematic synthesis of low-molecular weight fucoidan derivatives and their effect on cancer cells. Org. Biomol. Chem. 2015, 13, 10556-10568. [CrossRef] [PubMed]

102. Kim, E.J.; Park, S.Y.; Lee, J.-Y.; Park, J.H.Y. Fucoidan present in brown algae induces apoptosis of human colon cancer cells. BMC Gastroenterol. 2010, 10, 96. [CrossRef] [PubMed]

103. Lee, H.; Kim, J.S.; Kim, E. Fucoidan from seaweed Fucus vesiculosus inhibits migration and invasion of human lung cancer cell via PI3K-Akt-mTOR pathways. PLoS ONE 2012, 7, e50624. [CrossRef] [PubMed]

104. Schneider, T.; Ehrig, K.; Liewert, I.; Alban, S. Interference with the CXCL12/CXCR4 axis as potential antitumor strategy: Superiority of a sulfated galactofucan from the brown alga Saccharina latissima and Fucoidan over heparins. Glycobiology 2015, 25, 818-824. [CrossRef] [PubMed]

105. Koyanagi, S.; Tanigawa, N.; Nakagawa, H.; Soeda, S.; Shimeno, H. Oversulfation of fucoidan enhances its anti-angiogenic and antitumor activities. Biochem. Pharmacol. 2003, 65, 173-179. [CrossRef]

106. Fitton, J.H.; Stringer, D.N.; Karpiniec, S.S. Therapies from fucoidan: An update. Mar. Drugs 2015, 13, 5920-5946. [CrossRef] [PubMed]

107. Zhang, Z.; Till, S.; Jiang, C.; Knappe, S.; Reutterer, S.; Scheiflinger, F.; Szabo, C.M.; Dockal, M. Structure-activity relationship of the pro- and anticoagulant effects of Fucus vesiculosus fucoidan. Thromb. Haemost. 2014, 111, 429-437. [PubMed]

108. Lahrsen, E.; Schoenfeld, A.K.; Alban, S. Size-dependent pharmacological activities of differently degraded fucoidan fractions from Fucus vesiculosus. Carbohydr. Polym. 2018, 189, 162-168. [CrossRef] [PubMed]

109. Choi, J.; Kim, H.J. Preparation of low molecular weight fucoidan by gamma-irradiation and its anticancer activity. Carbohydr. Polym. 2013, 97, 358-362. [CrossRef] [PubMed]

110. Kwak, J.Y. Fucoidan as a marine anticancer agent in preclinical development. Mar. Drugs 2014, 12, 851-870. [CrossRef] [PubMed]

111. Wu, L.; Sun, J.; Su, X.; Yu, Q.; Yu, Q.; Zhang, P. A review about the development of fucoidan in antitumor activity: Progress and challenges. Carbohydr. Polym. 2016, 154, 96-111. [CrossRef] [PubMed]

112. Anastyuk, S.D.; Shevchenko, N.M.; Ermakova, S.P.; Vishchuk, O.S.; Nazarenko, E.L.; Dmitrenok, P.S.; Zvyagintseva, T.N. Anticancer activity in vitro of a fucoidan from the brown alga Fucus evanescens and its low-molecular fragments, structurally characterized by tandem mass-spectrometry. Carbohydr. Polym. 2012, 87, 186-194. [CrossRef]

113. Jang, J.Y.; Moon, S.Y.; Joo, H.G. Differential effects of fucoidans with low and high molecular weight on the viability and function of spleen cells. Food Chem. Toxicol. 2014, 68, 234-238. [CrossRef] [PubMed]

114. Schoenfeld, A.K.; Lahrsen, E.; Alban, S. Regulation of complement and contact system activation via C1 inhibitor potentiation and factor XIIa activity modulation by sulfated glycans-Structure-activity relationships. PLoS ONE 2016, 11, e0165493. [CrossRef] [PubMed] 
115. Ustyuzhanina, N.E.; Bilan, M.I.; Ushakova, N.A.; Usov, A.I.; Kiselevskiy, M.V.; Nifantiev, N.E. Fucoidans: Pro- or antiangiogenic agents? Glycobiology 2014, 24, 1265-1274. [CrossRef] [PubMed]

116. Hyun, J.-H.; Kim, S.-C.; Kang, J.-I.; Kim, M.-K.; Boo, H.-J.; Kwon, J.-M.; Koh, Y.-S.; Hyun, J.-W.; Park, D.-B.; Yoo, E.-S.; et al. Apoptosis inducing activity of fucoidan in HCT-15 colon carcinoma cells. Biol. Pharm. Bull. 2009, 32, 1760-1764. [CrossRef] [PubMed]

117. Kawamoto, H.; Miki, Y.; Kimura, T.; Tanaka, K.; Nakagawa, T.; Kawamukai, M.; Matsuda, H. Effects of fucoidan from mozuku on human stomach cell lines. Food Sci. Technol. Res. 2006, 12, 218-222. [CrossRef]

118. Vishchuk, O.S.; Sun, H.; Wang, Z.; Ermakova, S.P.; Xiao, J.; Lu, T.; Xue, P.; Zvyagintseva, T.N.; Xiong, H.; Shao, C.; et al. PDZ-binding kinase/T-LAK cell-originated protein kinase is a target of the fucoidan from brown alga Fucus evanescens in the prevention of EGF-induced neoplastic cell transformation and colon cancer growth. Oncotarget 2016, 7, 18763-18773. [CrossRef] [PubMed]

119. Azuma, K.; Ishihara, T.; Nakamoto, H.; Amaha, T.; Osaki, T.; Tsuka, T.; Imagawa, T.; Minami, S.; Takashima, O.; Ifuku, S.; et al. Effects of oral administration of fucoidan extracted from Cladosiphon okamuranus on tumor growth and survival time in a tumor-bearing mouse model. Mar. Drugs 2012, 10, 2337-2348. [CrossRef] [PubMed]

120. Suresh, V.; Anbazhagan, C.; Thangam, R.; Senthilkumar, D.; Senthilkumar, N.; Kannan, S.; Rengasamy, R.; Palani, P. Stabilization of mitochondrial and microsomal function of fucoidan from Sargassum plagiophyllum in diethylnitrosamine induced hepatocarcinogenesis. Carbohydr. Polym. 2013, 92, 1377-1385. [CrossRef] [PubMed]

121. Takeda, K.; Tomimori, K.; Kimura, R.; Ishikawa, C.; Nowling, T.K.; Mori, N. Anti-tumor activity of fucoidan is mediated by nitric oxide released from macrophages. Int. J. Oncol. 2012, 40, 251-260. [PubMed]

122. Ahmadi, A.; Zorofchian Moghadamtousi, S.; Abubakar, S.; Zandi, K. Antiviral potential of algae polysaccharides isolated from marine sources: A review. BioMed Res. Int. 2015, 2015, 10. [CrossRef] [PubMed]

123. Queiroz, K.C.S.; Medeiros, V.P.; Queiroz, L.S.; Abreu, L.R.D.; Rocha, H.A.O.; Ferreira, C.V.; Jucá, M.B.; Aoyama, H.; Leite, E.L. Inhibition of reverse transcriptase activity of HIV by polysaccharides of brown algae. BioMed Pharmacother. 2008, 62, 303-307. [CrossRef] [PubMed]

124. Zayed, A.; Muffler, K.; Hahn, T.; Rupp, S.; Finkelmeier, D.; Burger-Kentischer, A.; Ulber, R. Physicochemical and biological characterization of fucoidan from Fucus vesiculosus purified by dye affinity chromatography. Mar. Drugs 2016, 14, 79. [CrossRef] [PubMed]

125. Li, H.; Li, J.; Tang, Y.; Lin, L.; Xie, Z.; Zhou, J.; Zhang, L.; Zhang, X.; Zhao, X.; Chen, Z.; et al. Fucoidan from Fucus vesiculosus suppresses hepatitis B virus replication by enhancing extracellular signal-regulated Kinase activation. Virol. J. 2017, 14, 1-8. [CrossRef] [PubMed]

126. Pozharitskaya, O.N.; Shikov, A.N.; Faustova, N.M.; Obluchinskaya, E.D.; Kosman, V.M.; Vuorela, H.; Makarov, V.G. Pharmacokinetic and tissue distribution of fucoidan from Fucus vesiculosus after oral administration to rats. Mar. Drugs 2018, 16, 132. [CrossRef] [PubMed]

127. Byon, Y.Y.; Kim, M.H.; Yoo, E.S.; Hwang, K.K.; Jee, Y.; Shin, T.; Joo, H.G. Radioprotective effects of fucoidan on bone marrow cells: Improvement of the cell survival and immunoreactivity. J. Vet. Sci. 2008, 9, 359-365. [CrossRef] [PubMed]

128. Ku, M.J.; Jung, J.W.; Lee, M.S.; Cho, B.K.; Lee, S.R.; Lee, H.; Vischuk, O.S.; Zvyagintseva, T.N.; Ermakova, S.P.; Lee, Y.H. Effect of Fucus evanescens fucoidan on expression of matrix metalloproteinase-1 promoter, mRNA, protein and signal pathway. J. Life Sci. 2010, 20, 1603-1610. [CrossRef]

129. Chua, E.G.; Verbrugghe, P.; Perkins, T.T.; Tay, C.Y. Fucoidans disrupt adherence of helicobacter pylori to AGS cells in vitro. Evid.-Based Complement. Altern. Med. 2015, 2015, 1-6. [CrossRef] [PubMed]

130. Shibata, H.; Iimuro, M.; Uchiya, N.; Kawamori, T.; Nagaoka, M.; Ueyama, S.; Hashimoto, S.; Yokokura, T.; Sugimura, T.; Wakabayashi, K. Preventive effects of Cladosiphon fucoidan against Helicobacter pylori infection in Mongolian gerbils. Helicobacter 2003, 8, 59-65. [CrossRef] [PubMed]

131. Stiger-Pouvreau, V.; Bourgougnon, N.; Deslandes, E. Carbohydrates from Seaweeds. In Seaweed in Health and Disease Prevention; Fleurence, J., Levine, I., Eds.; Elsevier Inc.: New York, NY, USA, 2016; pp. 223-274.

132. Vera, J.; Castro, J.; Gonzalez, A.; Moenne, A. Seaweed polysaccharides and derived oligosaccharides stimulate defense responses and protection against pathogens in plants. Mar. Drugs 2011, 9, 2514-2525. [CrossRef] [PubMed] 
133. Rioux, L.; Turgeon, S.L.; Beaulieu, M. Phytochemistry Structural characterization of laminaran and galactofucan extracted from the brown seaweed Saccharina longicruris. Phytochemistry 2010, 71, 1586-1595. [CrossRef] [PubMed]

134. Graiff, A.; Ruth, W.; Kragl, U.; Karsten, U. Chemical characterization and quantification of the brown algal storage compound laminarin-A new methodological approach. J. Appl. Phycol. 2016, 28, 533-543. [CrossRef]

135. Ermakova, S.; Men'shova, R.; Vishchuk, O.; Kim, S.M.; Um, B.H.; Isakov, V.; Zvyagintseva, T. Water-soluble polysaccharides from the brown alga Eisenia bicyclis: Structural characteristics and antitumor activity. Algal Res. 2013, 2, 51-58. [CrossRef]

136. Ji, Y.B.; Ji, C.F.; Zhang, H.; Ji, Y. Bin Laminarin induces apoptosis of human colon cancer LoVo cells through a mitochondrial pathway. Molecules 2012, 17, 9947-9960. [CrossRef] [PubMed]

137. Xie, J.; Guo, L.; Ruan, Y.; Zhu, H.; Wang, L.; Zhou, L.; Yun, X.; Gu, J. Laminarin-mediated targeting to Dectin-1 enhances antigen-specific immune responses. Biochem. Biophys. Res. Commun. 2010, 391, 958-962. [CrossRef] [PubMed]

138. Ji, C.F.; Ji, Y. Bin Laminarin-induced apoptosis in human colon cancer LoVo cells. Oncol. Lett. 2014, 7, 1728-1732. [CrossRef] [PubMed]

139. Galland-Irmouli, A.V.; Fleurence, J.; Lamghari, R.; Luçon, M.; Rouxel, C.; Barbaroux, O.; Bronowicki, J.P.; Villaume, C.; Guéant, J.L. Nutritional value of proteins from edible seaweed Palmaria palmata (Dulse). J. Nutr. Biochem. 1999, 10, 353-359. [CrossRef]

140. Centro de Segurança Alimentar e Nutrição-Instituto Nacional de Saúde Dr. Ricardo Jorge. Tabela da Composição dos Alimentos. Available online: http:/ / portfir.insa.pt/ foodcomp/foodcompare?foodId=492\& foodIdForDelete $=492 \&$ foodId $=498 \&$ foodIdForDelete $=498$ (accessed on 25 July 2018).

141. Caracterização da Composição Nutricional da Macroalga Fucus vesiculosus e a Alteração dos Compostos Bioativos nos Diferentes Métodos de Secagem. Available online: https:/ / bibliotecadigital.ipb.pt/handle/ 10198/12592 (accessed on 25 July 2018).

142. Munda, I.M. Differences in amino acid composition of estuarine and marine fucoids. Aquat. Bot. 1977, 3 , 273-280. [CrossRef]

143. Ninomiya, K. Science of umami taste: Adaptation to gastronomic culture. Flavour 2015, 4, 13. [CrossRef]

144. Imbs, T.; Krasovskaya, N.; Ermakova, S.; Makarieva, T.; Shevchenko, N.; Zvyagintseva, T. Comparative study of chemical composition and antitumor activity of aqueous-ethanol extracts of brown algae Laminaria cichorioides, Costaria costata, and Fucus evanescens. Russ. J. Mar. Biol. 2009, 35, 164-170. [CrossRef]

145. Augier, H.; Santimone, M. Composition en azote total, en protéines et en acides aminés protéiques de fertilisant foliaire goémar, à base d'algues marines. Bot. Mar. 1978, 21, 337-341. [CrossRef]

146. Lorenzo, J.M.; Agregán, R.; Munekata, P.E.S.; Franco, D.; Carballo, J.; Şahin, S.; Lacomba, R.; Barba, F.J. Proximate composition and nutritional value of three macroalgae: Ascophyllum nodosum, Fucus vesiculosus and Bifurcaria bifurcata. Mar. Drugs 2017, 15, 360. [CrossRef] [PubMed]

147. Fleurence, J. Lipids, Fatty Acids, Glycolipids, and Phospholipids. In Seaweed in Health and Disease Prevention; Fleurence, J., Levine, I., Eds.; Academic Press Inc. Elsevier Science: Cambridge, MA, USA, 2016; pp. 185-222.

148. Nelson, M.M.; Phleger, C.F.; Nichols, P.D. Seasonal lipid composition in macroalgae of the northeastern Pacific Ocean. Bot. Mar. 2002, 45, 58-65. [CrossRef]

149. Schmid, M.; Guihéneuf, F.; Stengel, D.B. Fatty acid contents and profiles of 16 macroalgae collected from the Irish Coast at two seasons. J. Appl. Phycol. 2014, 26, 451-463. [CrossRef]

150. Pereira, H.; Barreira, L.; Figueiredo, F.; Custódio, L.; Vizetto-Duarte, C.; Polo, C.; Rešek, E.; Aschwin, E.; Varela, J. Polyunsaturated fatty acids of marine macroalgae: Potential for nutritional and pharmaceutical applications. Mar. Drugs 2012, 10, 1920-1935. [CrossRef] [PubMed]

151. Calder, P.C. Functional Roles of Fatty Acids and Their Effects on Human Health. J. Parenter. Enter. Nutr. 2015, 39, 18-32. [CrossRef] [PubMed]

152. Khotimchenko, S.V. Fatty acids of brown algae from the Russian Far East. Phytochemistry 1998, 49, $2363-2369$. [CrossRef]

153. Najdek, M.; Iveša, L.; Paliaga, P.; Blažina, M.; Čelig, A. Changes in the fatty acid composition of Fucus virsoides J. Agardh in response to the type of substratum. Acta Adriat. 2014, 55, 19-30. 
154. Maehre, H.K.; Malde, M.K.; Eilertsen, K.-E.; Elvevoll, E.O. Characterization of protein, lipid and mineral contents in common Norwegian seaweeds and evaluation of their potential as food and feed. J. Sci. Food Agric. 2014, 94, 3281-3290. [CrossRef] [PubMed]

155. Peinado, I.; Girón, J.; Koutsidis, G.; Ames, J.M. Chemical composition, antioxidant activity and sensory evaluation of five different species of brown edible seaweeds. Food Res. Int. 2014, 66, 36-44. [CrossRef]

156. Van Ginneken, V.J.T.; Helsper, J.P.F.G.; de Visser, W.; van Keulen, H.; Brandenburg, W.A. Polyunsaturated fatty acids in various macroalgal species from North Atlantic and tropical seas. Lipids Health Dis. 2011, 10, 104. [CrossRef] [PubMed]

157. Simopoulos, A.P. The importance of the ratio of omega-6/omega-3 essential fatty acids. Biomed. Pharmacother. 2002, 56, 365-379. [CrossRef]

158. Simopoulos, A. The importance of the omega- 6 / omega-3 fatty acid ratio in cardiovascular disease and other chronic diseases. Exp. Biol. Med. 2008, 233, 674-688. [CrossRef] [PubMed]

159. Hou, X.; Yan, X. Study on the concentration and seasonal variation of inorganic elements in 35 species of marine algae. Sci. Total Environ. 1998, 222, 141-156. [CrossRef]

160. Rupérez, P. Mineral content of edible marine seaweeds. Food Chem. 2002, 79, 23-26. [CrossRef]

161. Truus, K.; Vaher, M.; Koel, M.; Mähar, A.; Taure, I. Analysis of bioactive ingredients in the brown alga Fucus vesiculosus by capillary electrophoresis and neutron activation analysis. Anal. Bioanal. Chem. 2004, 379, 849-852. [CrossRef] [PubMed]

162. Macartain, P.; Gill, C.I.R.; Brooks, M.; Campbell, R.; Rowland, I.R. Nutritional value of edible seaweeds. Nutr. Rev. 2007, 2007, 535-543. [CrossRef]

163. Adrogué, H.J.; Madias, N.E. The impact of sodium and potassium on hypertension risk. Semin. Nephrol. 2014, 34, 257-272. [CrossRef] [PubMed]

164. Balina, K.; Romagnoli, F.; Blumberga, D. Chemical composition and potential use of Fucus vesiculosus from Gulf of Riga. Energy Procedia 2016, 95, 43-49. [CrossRef]

165. Teas, J.; Pino, S.; Critchley, A.; Braverman, L.E. Variability of iodine content in common commercially available edible seaweeds. Thyroid 2004, 14, 836-841. [CrossRef] [PubMed]

166. Ross, A.B.; Jones, J.M.; Kubacki, M.L.; Bridgeman, T. Classification of macroalgae as fuel and its thermochemical behaviour. Bioresour. Technol. 2008, 99, 6494-6504. [CrossRef] [PubMed]

167. Cabrita, A.R.J.; Maia, M.R.G.; Oliveira, H.M.; Sousa-Pinto, I.; Almeida, A.A.; Pinto, E.; Fonseca, A.J.M. Tracing seaweeds as mineral sources for farm-animals. J. Appl. Phycol. 2016, 28, 3135-3150. [CrossRef]

168. Van Netten, C.; Hoption Cann, S.A.; Morley, D.R.; Van Netten, J.P. Elemental and radioactive analysis of commercially available seaweed. Sci. Total Environ. 2000, 255, 169-175. [CrossRef]

169. Moro, C.O.; Basile, G. Obesity and medicinal plants. Fitoterapia 2000, 71, S73-S82. [CrossRef]

170. Balch, P.A.; Bell, S. Prescription for Herbal Healing, 2nd ed.; Penguin Group Inc.: London, UK, 2012.

171. Ramos-Peralonso, M.J. European Food Safety Authority (EFSA) Scientific Opinion on Dietary Reference Values for iodine. EFSA J. 2014, 12, 1-57.

172. Andersson, M.; De Benoist, B.; Darnton-Hill, I.; Delange, F. Iodine Deficiency in Europe: A Continuing Public Health Problem, 1st ed.; WHO: Geneva, Switzerland, 2007; pp. 1-86.

173. Davis, T.A.; Volesky, B.; Mucci, A. A review of the biochemistry of heavy metal biosorption by brown algae. Water Res. 2003, 37, 4311-4330. [CrossRef]

174. Rincón, J.; González, F.; Ballester, A.; Blázquez, M.L.; Muñoz, J.A. Biosorption of heavy metals by chemically-activated alga Fucus vesiculosus. J. Chem. Technol. Biotechnol. 2005, 80, 1403-1407. [CrossRef]

175. Ahmady-Asbchin, S.; Andres, Y.; Gerente, C.; Le Cloirec, P. Natural seaweed waste as sorbent for heavy metal removal from solution. Environ. Technol. 2009, 30, 755-762. [CrossRef] [PubMed]

176. Giusti, L. Heavy metal contamination of brown seaweed and sediments from the UK coastline between the Wear River and the Tees River. Environ. Int. 2001, 26, 275-286. [CrossRef]

177. Caliceti, M.; Argese, E.; Sfriso, A.; Pavoni, B. Heavy metal contamination in the seaweeds of the Venice lagoon. Chemosphere 2002, 47, 443-454. [CrossRef]

178. Coelho, J.P.; Pereira, M.E.; Duarte, A.; Pardal, M.A. Macroalgae response to a mercury contamination gradient in a temperate coastal lagoon (Ria de Aveiro, Portugal). Estuar. Coast. Shelf Sci. 2005, 65, 492-500. [CrossRef]

179. Choi, Y. International/National Standards for Heavy Metals in Food. Government Laboratory, 2011; pp. 1-13. Available online: https://www.govtlab.gov.hk/g/texchange/Stds\%20for\%20heavy\%20metals.pdf (accessed on 25 July 2018). 
180. World Health Organisation. Available online: http://www.who.int/mediacentre/factsheets/fs372/en/\#. WV5hlWgAVaM.mendeley (accessed on 25 July 2018).

181. Granchinho, S.C.R.; Polishchuk, E.; Cullen, W.R.; Reimer, K.J. Biomethylation and bioaccumulation of arsenic(V) by marine alga Fucus gardneri. Appl. Organomet. Chem. 2001, 15, 553-560. [CrossRef]

182. Geiszinger, A.; Goessler, W.; Pedersen, S.N.; Francesconi, K.A. Arsenic biotransformation by the brown macroalga Fucus serratus. Environ. Toxicol. Chem. 2001, 20, 2255-2262. [CrossRef] [PubMed]

183. Madsen, A.D.; Goessler, W.; Pedersen, S.N.; Francesconi, K.A. Characterization of an algal extract by HPLC-ICP-MS and LC-electrospray MS for use in arsenosugar speciation studies. J. Anal. At. Spectrom. 2000, 15, 657-662. [CrossRef]

184. U.S. Department of Agriculture USDA National Nutrient Database for Standard Reference, Release 28. 2016. Available online: http:/ / www.ars.usda.gov/ba/bhnrc/ndl (accessed on 25 July 2018).

185. Kraan, S. Pigments and minor compounds in algae. In Functional Ingredients from Algae for Foods and Nutraceuticals; Dominguez, H., Ed.; Woodhead Publishing Limited: Cambridge, UK, 2013; pp. 205-251.

186. Ransom, J.; Morgan, P.J.; McCaffery, P.J.; Stoney, P.N. The rhythm of retinoids in the brain. J. Neurochem. 2014, 129, 366-376. [CrossRef] [PubMed]

187. Analysis of Tocopherols and Tocotrienols by HPLC. Available online: http:/ /lipidlibrary.aocs.org/Analysis/ content.cfm?ItemNumber=40389 (accessed on 25 July 2018).

188. Kim, Y.; Kim, M.-G. HPLC-UV method for the simultaneous determinations of ascorbic acid and dehydroascorbic acid in human plasma. Transl. Clin. Pharmacol. 2016, 24, 37-42. [CrossRef]

189. Grosso, G.; Bei, R.; Mistretta, A.; Marventano, S.; Calabrese, G.; Masuelli, L.; Giganti, M.; Modesti, A.; Galvano, F.; Gazzolo, D. Effects of vitamin C on health: A review of evidence. Front. Biosci. 2013, 1, 1017-1029.

190. Abbaspour, N.; Hurrell, R.; Kelishadi, R. Review on iron and its importance for human health. J. Res. Med. Sci. 2014, 19, 164-174. [PubMed]

191. Martínez, J.P.; Araya, H. Ascorbate-glutathione cycle: Enzymatic and non-enzymatic integrated mechanisms and its biomolecular regulation. In Ascorbate-Glutathione Pathway and Stress Tolerance in Plants; Anjum, N.A., Umar, S., Chan, M.T., Eds.; Wiley Online Library: Hoboken, NJ, USA, 2010; Volume 23, pp. 303-322.

192. Niki, E. Role of vitamin E as lipid-soluble peroxyl radical scavenger: In vitro and in vivo evidence. Free Radic. Biol. Med. 2014, 66, 3-12. [CrossRef] [PubMed]

193. Azzi, A.; Stocker, A. Vitamin E: Non-antioxidant roles. Prog. Lipid Res. 2000, 39, 231-255. [CrossRef]

194. Jensen, A. Tocopherol content of seaweed and seaweed meal. J. Sciense Food Agric. 1969, 20, 454-458. [CrossRef]

195. Le Tutour, B.; Benslimane, F.; Gouleau, M.P.; Gouygou, J.P.; Saadan, B.; Quemeneur, F. Antioxidant and pro-oxidant activities of the brown algae, Laminaria digitata, Himanthalia elongata, Fucus vesiculosus, Fucus serratus and Ascophyllum nodosum. J. Appl. Phycol. 1998, 10, 121-129. [CrossRef]

196. Sytar, O.; Kumar, A.; Latowski, D.; Kuczynska, P.; Strzałka, K.; Prasad, M.N.V. Heavy metal-induced oxidative damage, defense reactions, and detoxification mechanisms in plants. Acta Physiol. Plant. 2013, 35, 985-999. [CrossRef]

197. Caracterização Química de Algas Disponíveis Comercialmente Para Consumo Humano. Available online: https:/ / repositorio-aberto.up.pt/bitstream/10216/84112/2/31718.pdf (accessed on 24 July 2017).

198. Tang, G. Bioconversion of dietary provitamin A carotenoids to vitamin A. in humans. Am. J. Clin. Nutr. 2010, 91, 1468S-1473S. [CrossRef] [PubMed]

199. Cardozo, K.H.M.; Guaratini, T.; Barros, M.P.; Falcão, V.R.; Tonon, A.P.; Lopes, N.P.; Campos, S.; Torres, M.A.; Souza, A.O.; Colepicolo, P.; et al. Metabolites from algae with economical impact. Comp. Biochem. Physiol. C Toxicol. Pharmacol. 2007, 146, 60-78. [CrossRef] [PubMed]

200. Collén, J.; Davison, I.R. Reactive oxygen metabolism in intertidal Fucus spp. (Phaeophyceae). J. Phycol. 1999, 35, 62-69. [CrossRef]

201. Mikami, K.; Hosokawa, M. Biosynthetic pathway and health benefits of fucoxanthin, an algae-specific xanthophyll in brown seaweeds. Int. J. Mol. Sci. 2013, 14, 13763-13781. [CrossRef] [PubMed]

202. Nakazawa, Y.; Sashima, T.; Hosokawa, M.; Miyashita, K. Comparative evaluation of growth inhibitory effect of stereoisomers of fucoxanthin in human cancer cell lines. J. Funct. Foods 2009, 1, 88-97. [CrossRef]

203. André Haugan, J.; Liaaen-Jensen, S. Improved isolation procedure for fucoxanthin. Phytochemistry 1989, 28, 2797-2798. [CrossRef] 
204. Haugan, J.A.; Liaaen-Jensen, S. Algal carotenoids 54. Carotenoids of brown algae (Phaeophyceae). Biochem. Syst. Ecol. 1994, 22, 31-41. [CrossRef]

205. Ramus, J.; Lemons, F.; Zimmerman, C. Adaptation of light-harvesting pigments to downwelling light and the consequent photosynthetic performance of the eulittoral rockweeds Ascophyllum nodosum and Fucus vesiculosus. Mar. Biol. 1977, 42, 293-303. [CrossRef]

206. Kang, S.I.; Ko, H.C.; Shin, H.S.; Kim, H.M.; Hong, Y.S.; Lee, N.H.; Kim, S.J. Fucoxanthin exerts differing effects on 3T3-L1 cells according to differentiation stage and inhibits glucose uptake in mature adipocytes. Biochem. Biophys. Res. Commun. 2011, 409, 769-774. [CrossRef] [PubMed]

207. Ha, A.W.; Kim, W.K. The effect of fucoxanthin rich power on the lipid metabolism in rats with a high fat diet. Nutr. Res. Pract. 2013, 7, 287-293. [CrossRef] [PubMed]

208. Woo, M.-N.; Jeon, S.-M.; Shin, Y.C.; Lee, M.-K.; Kang, M.A.; Choi, M.-S. Anti-obese property of fucoxanthin is partly mediated by altering lipid-regulating enzymes and uncoupling proteins of visceral adipose tissue in mice. Mol. Nutr. Food Res. 2009, 53, 1603-1611. [CrossRef] [PubMed]

209. Maeda, H.; Hosokawa, M.; Sashima, T.; Funayama, K.; Miyashita, K. Fucoxanthin from edible seaweed, Undaria pinnatifida, shows antiobesity effect through UCP1 expression in white adipose tissues. Biochem. Biophys. Res. Commun. 2005, 332, 392-397. [CrossRef] [PubMed]

210. Maeda, H.; Hosokawa, M.; Sashima, T.; Miyashita, K. Dietary combination of fucoxanthin and fish oil attenuates the weight gain of white adipose tissue and decreases blood glucose in obese/diabetic KK-Ay mice. J. Agric. Food Chem. 2007, 55, 7701-7706. [CrossRef] [PubMed]

211. Park, H.J.; Lee, M.K.; Park, Y.B.; Shin, Y.C.; Choi, M.S. Beneficial effects of Undaria pinnatifida ethanol extract on diet-induced-insulin resistance in C57BL/6J mice. Food Chem. Toxicol. 2011, 49, 727-733. [CrossRef] [PubMed]

212. Airanthi, M.K.W.A.; Hosokawa, M.; Miyashita, K. Comparative antioxidant activity of ediblejapanese brown seaweeds. J. Food Sci. 2011, 76, 104-111. [CrossRef] [PubMed]

213. Zaragozá, M.C.; López, D.; Sáiz, M.P.; Poquet, M.; Pérez, J.; Puig-Parellada, P.; Màrmol, F.; Simonetti, P.; Gardana, C.; Lerat, Y.; et al. Toxicity and antioxidant activity in vitro and in vivo of two Fucus vesiculosus extracts. J. Agric. Food Chem. 2008, 56, 7773-7780. [CrossRef] [PubMed]

214. Peng, J.; Yuan, J.P.; Wu, C.F.; Wang, J.H. Fucoxanthin, a marine carotenoid present in brown seaweeds and diatoms: Metabolism and bioactivities relevant to human health. Mar. Drugs 2011, 9, 1806-1828. [CrossRef] [PubMed]

215. Heo, S.J.; Ko, S.C.; Kang, S.M.; Kang, H.S.; Kim, J.P.; Kim, S.H.; Lee, K.W.; Cho, M.G.; Jeon, Y.J. Cytoprotective effect of fucoxanthin isolated from brown algae Sargassum siliquastrum against $\mathrm{H}_{2} \mathrm{O}_{2}$-induced cell damage. Eur. Food Res. Technol. 2008, 228, 145-151. [CrossRef]

216. Liu, C.L.; Chiu, Y.T.; Hu, M.L. Fucoxanthin enhances HO-1 and NQO1 expression in murine hepatic BNL CL.2 Cells through activation of the Nrf2/ARE system partially by its pro-oxidant activity. J. Agric. Food Chem. 2011, 59, 11344-11351. [CrossRef] [PubMed]

217. Heo, S.J.; Yoon, W.J.; Kim, K.N.; Oh, C.; Choi, Y.U.; Yoon, K.T.; Kang, D.H.; Qian, Z.J.; Choi, I.W.; Jung, W.K. Anti-inflammatory effect of fucoxanthin derivatives isolated from Sargassum siliquastrum in lipopolysaccharide-stimulated RAW 264.7 macrophage. Food Chem. Toxicol. 2012, 50, 3336-3342. [CrossRef] [PubMed]

218. Kim, K.-N.; Heo, S.-J.; Yoon, W.-J.; Kang, S.-M.; Ahn, G.; Yi, T.-H.; Jeon, Y.-J. Fucoxanthin inhibits the inflammatory response by suppressing the activation of NF- $\mathrm{KB}$ and MAPKs in lipopolysaccharide-induced RAW 264.7 macrophages. Eur. J. Pharmacol. 2010, 649, 369-375. [CrossRef] [PubMed]

219. Heo, S.-J.; Yoon, W.-J.; Kim, K.-N.; Ahn, G.-N.; Kang, S.-M.; Kang, D.-H.; Affan, A.; Oh, C.; Jung, W.-K.; Jeon, Y.-J. Evaluation of anti-inflammatory effect of fucoxanthin isolated from brown algae in lipopolysaccharide-stimulated RAW 264.7 macrophages. Food Chem. Toxicol. 2010, 48, 2045-2051. [CrossRef] [PubMed]

220. Kim, K.-N.; Heo, S.-J.; Kang, S.-M.; Ahn, G.; Jeon, Y.-J. Fucoxanthin induces apoptosis in human leukemia HL-60 cells through a ROS-mediated Bcl-xL pathway. Toxicol. Vitr. 2010, 24, 1648-1654. [CrossRef] [PubMed]

221. Kotake-Nara, E.; Asai, A.; Nagao, A. Neoxanthin and fucoxanthin induce apoptosis in PC-3 human prostate cancer cells. Cancer Lett. 2005, 220, 75-84. [CrossRef] [PubMed]

222. Kotake-Nara, E.; Terasaki, M.; Nagao, A. Characterization of apoptosis induced by fucoxanthin in human promyelocytic leukemia cells. Biosci. Biotechnol. Biochem. 2005, 69, 224-227. [CrossRef] [PubMed] 
223. Yoshiko, S.; Hoyoko, N. Fucoxanthin, a natural carotenoid, induces G1 arrest and GADD45 gene expression in human cancer cells. In Vivo 2007, 21, 305-309. [PubMed]

224. Das, S.K.; Hashimoto, T.; Kanazawa, K. Growth inhibition of human hepatic carcinoma HepG2 cells by fucoxanthin is associated with down-regulation of cyclin D. Biochim. Biophys. Acta BBA Gen. Subj. 2008, 1780, 743-749. [CrossRef] [PubMed]

225. Liu, C.-L.; Huang, Y.-S.; Hosokawa, M.; Miyashita, K.; Hu, M.-L. Inhibition of proliferation of a hepatoma cell line by fucoxanthin in relation to cell cycle arrest and enhanced gap junctional intercellular communication. Chem. Biol. Interact. 2009, 182, 165-172. [CrossRef] [PubMed]

226. Shannon, E.; Abu-Ghannam, N. Optimisation of fucoxanthin extraction from Irish seaweeds by response surface methodology. J. Appl. Phycol. 2017, 29, 1027-1036. [CrossRef]

227. Global Fucoxanthin Market 2016 Industry Trends, Sales, Supply, Demand, Analysis and Forecast to 2021. Available online: http:/ / www.pdf.mrsresearchgroup.com/market-analysis/global-fucoxanthin-market2016-production-sales-supply-demand.pdf (accessed on 24 July 2018).

228. Li, Y.-X.X.; Wijesekara, I.; Li, Y.-X.X.; Kim, S.-K.K. Phlorotannins as bioactive agents from brown algae. Process Biochem. 2011, 46, 2219-2224. [CrossRef]

229. Pal Singh, I.; Bharate, S.B. Phloroglucinol compounds of natural origin. Nat. Prod. Rep. 2006, $23,558-591$. [CrossRef] [PubMed]

230. Glombitza, K.W.; Rauwald, H.W.; Eckhardt, G. Fucole, polyhydroxyoligophenyle aus Fucus vesiculosus. Phytochemistry 1975, 14, 1403-1405. [CrossRef]

231. Craige, J.S.; McInnes, A.G.; Ragan, M.A.; Walter, J.A. Chemical constituents of the physodes of brown algae. Characterization by $1 \mathrm{H}$ and $13 \mathrm{C}$ nuclear magnetic resonance spectroscopy of oligomers of phloroglucinol from Fucus vesiculosus (L.). Can. J. Chem. 1977, 55, 1575-1582. [CrossRef]

232. Glombitza, K.; Rauwald, H.; Eckhardt, G. Fucophloretholes, Polyhydroxyoligophenyl ethers from Fucus vesiculosus. Planta Medica 1977, 32, 33-45. [CrossRef]

233. Steevensz, A.J.; MacKinnon, S.L.; Hankinson, R.; Craft, C.; Connan, S.; Stengel, D.B.; Melanson, J.E. Profiling phlorotannins in brown macroalgae by liquid chromatography-high resolution mass spectrometry. Phytochem. Anal. 2012, 23, 547-553. [CrossRef] [PubMed]

234. Parys, S.; Kehraus, S.; Krick, A.; Glombitza, K.W.; Carmeli, S.; Klimo, K.; Gerhäuser, C.; König, G.M. In vitro chemopreventive potential of fucophlorethols from the brown alga Fucus vesiculosus L. by anti-oxidant activity and inhibition of selected cytochrome P450 enzymes. Phytochemistry 2010, 71, 221-229. [CrossRef] [PubMed]

235. Connan, S.; Goulard, F.; Stiger, V.; Deslandes, E.; Gall, E.A. Interspecific and temporal variation in phlorotannin levels in an assemblage of brown algae. Bot. Mar. 2004, 47, 410-416. [CrossRef]

236. Connan, S.; Stengel, D.B. Impacts of ambient salinity and copper on brown algae: 2 . Interactive effects on phenolic pool and assessment of metal binding capacity of phlorotannin. Aquat. Toxicol. 2011, 104, 1-13. [CrossRef] [PubMed]

237. Pedersen, A. Studies on phenol content and heavy metal uptake in fucoids. In Proceedings of the Eleventh International Seaweed Symposium, Qingdao, China, 19-25 June 1983; Bird, C.J., Ragan, M.A., Eds.; Springer: Dordrecht, The Netherlands, 1984; pp. 498-504.

238. Pavia, H.; Toth, G.B. Influence of light and nitrogen on the phlorotannin content of the brown seaweeds Ascophyllum nodosum and Fucus vesiculosus. In Hydrobiologia; Jones, M.B., Azevedo, J.M.N., Neto, A.I., Costa, A.C., Martins, A.M.F., Eds.; Kluwer Academic Publishers: Dordrecht, The Netherlands, 2000; Volume 440, pp. 299-305.

239. Zubia, M.; Fabre, M.S.; Kerjean, V.; Lann, K.L.; Stiger-Pouvreau, V.; Fauchon, M.; Deslandes, E. Antioxidant and antitumoural activities of some Phaeophyta from Brittany coasts. Food Chem. 2009, 116, 693-701. [CrossRef]

240. Ferreres, F.; Lopes, G.; Gil-Izquierdo, A.; Andrade, P.B.; Sousa, C.; Mouga, T.; Valentão, P. Phlorotannin extracts from fucales characterized by HPLC-DAD-ESI-MSn: Approaches to hyaluronidase inhibitory capacity and antioxidant properties. Mar. Drugs 2012, 10, 2766-2781. [CrossRef] [PubMed]

241. Heffernan, N.; Brunton, N.P.; FitzGerald, R.J.; Smyth, T.J. Profiling of the molecular weight and structural isomer abundance of macroalgae-derived phlorotannins. Mar. Drugs 2015, 13, 509-528. [CrossRef] [PubMed] 
242. Wang, T.; Jónsdóttir, R.; Liu, H.; Gu, L.; Kristinsson, H.G.; Raghavan, S.; Ólafsdóttir, G. Antioxidant capacities of phlorotannins extracted from the brown algae Fucus vesiculosus. J. Agric. Food Chem. 2012, 60, 5874-5883. [CrossRef] [PubMed]

243. O'Sullivan, A.M.; O'Callaghan, Y.C.; O'Grady, M.N.; Queguineur, B.; Hanniffy, D.; Troy, D.J.; Kerry, J.P.; $\mathrm{O}^{\prime}$ Brien, N.M. In vitro and cellular antioxidant activities of seaweed extracts prepared from five brown seaweeds harvested in spring from the west coast of Ireland. Food Chem. 2011, 126, 1064-1070. [CrossRef]

244. Hermund, D.B.; Plaza, M.; Turner, C.; Jónsdóttir, R.; Kristinsson, H.G.; Jacobsen, C.; Nielsen, K.F. Structure dependent antioxidant capacity of phlorotannins from Icelandic Fucus vesiculosus by UHPLC-DAD-ECD-QTOFMS. Food Chem. 2018, 240, 904-909. [CrossRef] [PubMed]

245. Kellogg, J.; Esposito, D.; Grace, M.H.; Komarnytsky, S.; Lila, M.A. Alaskan seaweeds lower inflammation in RAW 264.7 macrophages and decrease lipid accumulation in 3T3-L1 adipocytes. J. Funct. Foods 2015, 15, 396-407. [CrossRef]

246. Bahar, B.; O’Doherty, J.V.; Hayes, M.; Sweeney, T. Extracts of brown seaweeds can attenuate the bacterial lipopolysaccharide-induced pro-inflammatory response in the porcine colon ex vivo. J. Anim. Sci. 2012, 90, 46-48. [CrossRef] [PubMed]

247. Bahar, B.; Doherty, J.V.O.; Smyth, T.J.; Ahmed, A.M.; Sweeney, T. A cold water extract of Fucus vesiculosus inhibits lipopolysaccharide (LPS) induced pro-inflammatory responses in the porcine colon ex-vivo model. Innov. Food Sci. Emerg. Technol. 2016, 37, 229-236. [CrossRef]

248. Kellogg, J.; Grace, M.H.; Lila, M.A. Phlorotannins from alaskan seaweed inhibit carbolytic enzyme activity. Mar. Drugs 2014, 12, 5277-5294. [CrossRef] [PubMed]

249. Roy, M.C.; Anguenot, R.; Fillion, C.; Beaulieu, M.; Bérubé, J.; Richard, D. Effect of a commercially-available algal phlorotannins extract on digestive enzymes and carbohydrate absorption in vivo. Food Res. Int. 2011, 44, 3026-3029. [CrossRef]

250. Paradis, M.; Couture, P.; Lamarche, B. A randomised crossover placebo-controlled trial investigating the effect of brown seaweed (Ascophyllum nodosum and Fucus vesiculosus) on postchallenge plasma glucose and insulin in men and women. Appl. Physiol. Nutr. Metab. 2011, 36, 913-919. [CrossRef] [PubMed]

251. Catarino, D.M.; Silva, M.A.; Cardoso, M.S. Fucaceae: A Source of Bioactive Phlorotannins. Int. J. Mol. Sci. 2017, 18, 1327. [CrossRef] [PubMed]

252. Kang, N.-J.; Han, S.-C.; Kang, G.-J.; Koo, D.-H.; Koh, Y.-S.; Hyun, J.-W.; Lee, N.-H.; Ko, M.-H.; Kang, H.-K.; Yoo, E.-S. Diphlorethohydroxycarmalol inhibits interleukin-6 production by regulating NF-KB, STAT5 and SOCS1 in lipopolysaccharide-stimulated RAW264.7 cells. Mar. Drugs 2015, 13, 2141-2157. [CrossRef] [PubMed]

253. Geisen, U.; Zenthoefer, M.; Peipp, M.; Kerber, J.; Plenge, J.; Managò, A.; Fuhrmann, M.; Geyer, R.; Hennig, S.; Adam, D.; et al. Molecular mechanisms by which a Fucus vesiculosus extract mediates cell cycle inhibition and cell death in pancreatic cancer cells. Mar. Drugs 2015, 13, 4470-4491. [CrossRef] [PubMed]

254. Zenthoefer, M.; Geisen, U.; Hofmann-peiker, K.; Fuhrmann, M.; Geyer, R.; Piker, L.; Kalthoff, H.; Fuhrmann, M.; Kerber, J.; Kirchhöfer, R.; et al. Isolation of polyphenols with anticancer activity from the Baltic Sea brown seaweed Fucus vesiculosus using bioassay-guided fractionation. J. Appl. Phycol. 2017, 148, 1-17. [CrossRef]

255. Lopes, G.; Pinto, E.; Andrade, P.B.; Valentão, P. Antifungal activity of phlorotannins against dermatophytes and yeasts: Approaches to the mechanism of action and influence on Candida albicans virulence factor. PLoS ONE 2013, 8, e72203. [CrossRef] [PubMed]

256. Lopes, G.; Sousa, C.; Silva, L.R.; Pinto, E.; Andrade, P.B.; Bernardo, J.; Mouga, T.; Valentão, P. Can phlorotannins purified extracts constitute a novel pharmacological alternative for microbial infections with associated inflammatory conditions? PLOS ONE 2012, 7, e31145. [CrossRef] [PubMed]

257. Paiva, L.; Lima, E.; Neto, A.I.; Baptista, J. Angiotensin I-converting enzyme (ACE) inhibitory activity of Fucus spiralis macroalgae and influence of the extracts storage temperature-A short report. J. Pharm. Biomed. Anal. 2016, 131, 503-507. [CrossRef] [PubMed]

258. Guinea, M.; Franco, V.; Araujo-Bazán, L.; Rodríguez-Martín, I.; González, S. In vivo UVB-photoprotective activity of extracts from commercial marine macroalgae. Food Chem. Toxicol. 2012, 50, 1109-1117. [CrossRef] [PubMed]

259. Plaza, M.; Cifuentes, A.; Ibáñez, E. In the search of new functional food ingredients from algae. Trends Food Sci. Technol. 2008, 19, 31-39. [CrossRef] 
260. Seaweed on Track to Become Europe's Next Big Superfood Trend. Available online: https: / / www.seafoodsource.com/news/food-safety-health/seaweed-on-track-to-become-europe-s-nextbig-superfood-trend (accessed on 24 July 2018).

261. Dellarosa, N.; Laghi, L.; Martinsdóttir, E.; Jónsdóttir, R.; Sveinsdóttir, K. Enrichment of convenience seafood with omega-3 and seaweed extracts: Effect on lipid oxidation. LWT Food Sci. Technol. 2015, 62, 746-752. [CrossRef]

262. Jónsdóttir, R.; Geirsdóttir, M.; Hamaguchi, P.Y.; Jamnik, P.; Kristinsson, H.G.; Undeland, I. The ability of in vitro antioxidant assays to predict the efficiency of a cod protein hydrolysate and brown seaweed extract to prevent oxidation in marine food model systems. J. Sci. Food Agric. 2016, 96, 2125-2135. [CrossRef] [PubMed]

263. Wang, T.; Jónsdóttir, R.; Kristinsson, H.G.; Thorkelsson, G.; Jacobsen, C.; Hamaguchi, P.Y.; Ólafsdóttir, G. Inhibition of haemoglobin-mediated lipid oxidation in washed cod muscle and cod protein isolates by Fucus vesiculosus extract and fractions. Food Chem. 2010, 123, 321-330. [CrossRef]

264. Halldorsdottir, S.M.; Sveinsdottir, H.; Gudmundsdottir, A.; Thorkelsson, G.; Kristinsson, H.G. High quality fish protein hydrolysates prepared from by-product material with Fucus vesiculosus extract. J. Funct. Foods 2014, 9, 10-17. [CrossRef]

265. Halldorsdottir, S.M.; Kristinsson, H.G.; Sveinsdottir, H.; Thorkelsson, G.; Hamaguchi, P.Y. The effect of natural antioxidants on haemoglobin-mediated lipid oxidation during enzymatic hydrolysis of cod protein. Food Chem. 2013, 141, 914-919. [CrossRef] [PubMed]

266. Karadağ, A.; Hermund, D.B.; Jensen, L.H.S.; Andersen, U.; Jónsdóttir, R.; Kristinsson, H.G.; Alasalvar, C.; Jacobsen, C. Oxidative stability and microstructure of $5 \%$ fish-oil-enriched granola bars added natural antioxidants derived from brown alga Fucus vesiculosus. Eur. J. Lipid Sci. Technol. 2017, 119, 1-12. [CrossRef]

267. Honold, P.J.; Jacobsen, C.; Jónsdóttir, R.; Kristinsson, H.G.; Hermund, D.B. Potential seaweed-based food ingredients to inhibit lipid oxidation in fish-oil-enriched mayonnaise. Eur. Food Res. Technol. 2015, 242, 571-584. [CrossRef]

268. Agregán, R.; Munekata, P.E.; Domínguez, R.; Carballo, J.; Franco, D.; Lorenzo, J.M. Proximate composition, phenolic content and in vitro antioxidant activity of aqueous extracts of the seaweeds Ascophyllum nodosum, Bifurcaria bifurcata and Fucus vesiculosus. Effect of addition of the extracts on the oxidative stability of c. Food Res. Int. 2017, 99, 986-994. [CrossRef] [PubMed]

269. Produção e Caracterização da Capacidade Antioxidante de gelo Suplementado com Extrato de Fucus spiralis. Available online: https:/ /iconline.ipleiria.pt/handle/10400.8/593 (accessed on 25 July 2018).

270. Miranda, J.M.; Trigo, M.; Barros-Velázquez, J.; Aubourg, S.P. Effect of an icing medium containing the alga Fucus spiralis on the microbiological activity and lipid oxidation in chilled megrim (Lepidorhombus whiffiagonis). Food Control. 2016, 59, 290-297. [CrossRef] 